\title{
A little Parthenon no longer: the proportionality of tobacco packaging restrictions on autonomous communication, political expression and commercial speech
}

\author{
EOIN O'DELL*
}

Trinity College Dublin

\begin{abstract}
This paper evaluates the constitutionality of statutory restrictions upon tobacco packaging in Ireland. It concludes that public bealth and the protection of children constitute pressing and substantial reasons sufficient to justify the Public Health (Standardised Packaging of Tobacco) Act 2015 and part 5 of the Health (Miscellaneous Provisions) Act 2017 as proportionate restrictions upon tobacco companies' freedom of political expression protected by Article 40.6.1 of the Constitution and freedom of autonomous communication protected by Article 40.3.1.
\end{abstract}

Keywords: Irish Constitution; plain tobacco packaging; freedom of speech, political expression, autonomous communication; pressing and substantial reasons; proportionality.

\section{Introduction}

A ttractive packaging is an important element of a product's effective marketing. ${ }^{1}$ Indeed, Aso central has packaging been to the allure of smoking that Leonard Cohen could extol 'the little Parthenon / of an opened pack of cigarettes'. ${ }^{2}$ Hence, the control of packaging has become an important plank in the public health responses to tobacco.

Fellow and Associate Professor, School of Law, Trinity College Dublin. I would like to thank Mark Bell, Mairead Brady, Niamh Connelly, David Kenny, Caoimhín Mac Maoláin, Deirdre Ní Fhloinn, Rachael Walsh, and Gerry Whyte for their help with this article. An earlier version of this paper was delivered at the ICON-S British and Irish Chapter Inaugural Conference, Trinity College Dublin, Ireland, on 5 September 2017. All links in these notes were last visited on 1 May 2018.

1 Nora Lado Cousté, Mercedes Martos-Partal and Ester Martínez-Ros, 'The Power of a Package. Product Claims Drive Purchase Decisions' (2012) 52(3) Journal of Advertising Research 364; see generally Philip Kotler, Kevin Keller, Mairead Brady, Malcolm Goodman and Torben Hansen, Marketing Management (3rd edn, Pearson 2016) chs 10 and 17.

2 Leonard Cohen, 'The Cigarette Issue' in Book of Longing (McClelland \& Stewart, Toronto 2006) 71. Cohen celebrated 'the beauty / and the salvation / of cigarettes' (ibid); he posed for many iconic photographs flourishing lit cigarettes, including for the cover of his valedictory album You Want it Darker (Columbia 2016); and, having given up smoking at 69, he restarted on his 80th birthday (Jason Karlawish, 'Too Young to Die, Too Old to Worry' New York Times (New York, 20 September 2014) SR5). On the other hand, his anthemic 'Everybody Knows', with his cigarette-gravelled voice, was used as the soundtrack to a famous anti-smoking television advertisement commissioned by the New South Wales government and first broadcast during coverage of the Beijing Olympics in 2008 ('Games Viewers Get Shock Anti-smoking Ad' Sydney Morning Herald (Sydney, 16 August 2008)). 
On 10 March 2015, Ireland became the second country in the world - after Australia ${ }^{3}$ - to enact legislation requiring standardised packaging of tobacco, when the President signed the Public Health (Standardised Packaging of Tobacco) Act 2015. On 16 February 2017, the standardised packaging rules were strengthened, when the President signed the Health (Miscellaneous Provisions) Act 2017, part 5 of which amends the 2015 Act. ${ }^{4}$ Those parts of the 2015 Act that were not to be amended by the Bill which became the 2017 Act were brought into force on 20 May 2016; $;^{5}$ the remainder - including some of the core packaging regulations - came into force on 29 September $2017 .{ }^{6}$

The regulations in the packaging legislation prohibit all forms of branding (including trade marks) from appearing on tobacco packaging, except for brand names, which will have to be presented in a standard typeface for every brand on the market. Moreover, all packs will have to be in the same prescribed plain neutral colour, except for mandatory health warnings.

Although early legislation mainly covered excise matters, ${ }^{7}$ in Ireland - in common with the rest of the world ${ }^{8}$ - tobacco is now increasingly being regulated for public health reasons, ${ }^{9}$ and the current packaging legislation is simply the most recent example in a long line of tobacco control legislation. Hence, the regulation of tobacco advertising began in $1978,{ }^{10}$ and the regulation of the sale of tobacco products began in earnest in $1988 .{ }^{11}$

Following a report by a parliamentary committee in 1999 recommending a National Anti-Smoking Strategy, ${ }^{12}$ and a report for the Department of Health in 2000 recommending

3 The Tobacco Plain Packaging Act 2011 (Cth) as implemented by the Tobacco Plain Packaging Regulations 2011 (Cth) (SLI 263/2011) (as amended); see also the Trade Marks Amendment (Tobacco Plain Packaging) Act 2011 (Cth).

4 The Public Health (Standardised Packaging of Tobacco) Act 2015 and part 5 of the Health (Miscellaneous Provisions) Act 2017 are hereafter referred to simply as the packaging legislation.

5 The Public Health (Standardised Packaging of Tobacco) Act 2015 (Commencement) Order 2016 (SI 270/2016) substantially commenced the 2015 Act. In terms of commencement, the Irish Act had been overtaken by the subsequently enacted equivalent UK provisions (see s 94 of the Children and Families Act 2014, commenced by the Children and Families Act 2014 (Commencement No 4) Order 2014 (SI 2609/2014) and the Children and Families Act 2014 (Commencement No 6) Order 2015 (SI 375/ 2015) and implemented by the Standardised Packaging of Tobacco Products Regulations 2015 (SI 829/2015) which came into force on the same day as the 2015 Act in Ireland.

6 See the Public Health (Standardised Packaging of Tobacco) Act 2015 (Commencement) Order 2017 (SI 115/2016); they were given significant further effect by the Public Health (Standardised Packaging of Tobacco) Regulations 2017 (SI 422/2017) (the 2017 Regulations) which came into effect on 30 September 2017. There is a transition period of one year, so that all tobacco products will have to conform with standardised packaging from 30 September 2018, though some conforming packages have already begun to appear in the shops: 'First of Plain Cigarette Packets Hit Shelves around the Country' Irish Independent (Dublin, 22 February 2018); 'The Future of Cigarette Packets Is Here and It's Plain' Press Release (Department of Health, 22 February 2018) < http://health.gov.ie/blog/press-release/the-future-of-cigarette-packets-is-hereand-its-plain $>$. Having been the second country to enact the necessary legislation, the relatively protracted process of amendment meant that Ireland was the fifth country to bring such legislation into force, after Australia, the UK (see n 5 above), Norway and France; see 'Plain Packs Proliferating' (Framework Convention Alliance, 29 August 2017) <www.fctc.org/fca-news/opinion-pieces/1520-plain-packs-proliferating>.

7 The Tobacco Act 1934; the Finance (Excise Duty on Tobacco Products) Act 1977.

8 See, generally, Geraint Howells, The Tobacco Challenge: Legal Policy and Consumer Protection (Ashgate, London 2011; republished Routledge, London 2016); Tania Voon, Andrew Mitchell and Jonathan Liberman (eds), Regulating Tobacco, Alcohol and Unhealthy Foods: The Legal Issues (Routledge, London 2014).

9 Peter Boyle, Nigel Gray, Jack Henningfield, John Seffrin and Witold Zatonski, Tobacco, Science, Policy and Public Health (2nd edn, Oxford University Press 2010).

10 The Tobacco Products (Control of Advertising, Sponsorship and Sales Promotion) Act 1978.

11 The Tobacco (Health Promotion and Protection) Act 1988. The government did not proceed with plans to include a ban on public smoking in that Act (see National Archives of Ireland, 2016/51/392).

12 The Oireachtas Joint Committee on Health and Children, National Anti-Smoking Strategy (Dublin 1999). 
that Ireland should move towards a tobacco-free society, ${ }^{13}$ the Public Health (Tobacco) Act 2002 banned advertising and sponsorship by tobacco companies, and it introduced a comprehensive system of regulation of sale and consumption of tobacco products. In particular, this Act included the world's first outright ban on smoking in the workplace. ${ }^{14}$ And it is still the foundation for the current system of tobacco control in Ireland. ${ }^{15}$ It was amended in $2004,{ }^{16}$ to implement two European directives, ${ }^{17}$ and to give effect to the World Health Organization (WHO) Framework Convention on Tobacco Control 2003. ${ }^{18}$ Most recently, following a report for the Department of Health in 2013 recommending a tobacco-free Ireland ${ }^{19}$ by 2025 , smoking is now prohibited in cars in which children are present, ${ }^{20}$ the 2015 Act implemented another European directive, ${ }^{21}$ and the packaging legislation now requires standardised packaging of tobacco products.

13 Towards a Tobacco-Free Society (Report of the Tobacco-Free Policy Review Group, Dublin 2000).

14 See s 47 of the 2002 Act, and the Tobacco Smoking (Prohibition) Regulations 2003 (SI 481/2003). The Report on the Health Effects of Environmental Tobacco Smoke (ETS) in the Workplace (Health and Safety Authority/Office of Tobacco Control, Dublin 2002) recommended this ban.

15 As amended, inter alia, by the Public Health (Tobacco) (Amendment) Act 2009, the Public Health (Tobacco) (Amendment) Act 2010, the Public Health (Tobacco) (Amendment) Act 2011 and the Public Health (Tobacco) (Amendment) Act 2013.

16 By the Public Health (Tobacco) (Amendment) Act 2004.

17 Directive 2001/37/EC of the European Parliament and of the Council of 5 June 2001 on the Approximation of the Laws, Regulations and Administrative Provisions of the Member States Concerning the Manufacture, Presentation and Sale of Tobacco Products ((2001) OJ L 194); and Directive 2003/33/EC of the European Parliament and of the Council of 26 May 2003 on the Approximation of the Laws, Regulations and Administrative Provisions of the Member States Relating to the Advertising and Sponsorship of Tobacco Products ((2003) OJ L 152).

18 Geneva, 21 May 2003; see 2302 United Nations Treaty Series 166. Ireland signed the Convention on 16 September 2003 and, by virtue of the 2004 Act, ratified it on 7 November 2005; see $<$ https://treaties.un.org/pages/ViewDetails.aspx?src=TREATY\&mtdsg_no=IX4\&chapter=9\&clang=_en>. See generally Oscar Cabrera and Lawrence Gostin, 'Human Rights and the Framework Convention on Tobacco Control: Mutually Reinforcing Systems’ (2011) 7(3) International Journal of Law in Context 285; Benn McGrady, Trade and Public Health: The WTO, Tobacco, Alcohol, and Diet (Cambridge University Press 2011); Kate Lannan, 'The WHO Framework Convention on Tobacco Control: The International Context for Plain Packaging' in Tania Voon, Andrew Mitchell and Jonathan Liberman, with Glyn Ayres (eds), Public Health and Plain Packaging of Cigarettes. Legal Issues (Edward Elgar, Cheltenham 2012) ch 2; Lawrence Gostin and Eric Friedman, 'Towards a Framework Convention on Global Health: A Transformative Agenda for Global Health Justice’ (2013) 13 Yale Journal of Health Policy, Law and Ethics 1; Lawrence Gostin, Global Health Law (Harvard University Press 2014); Matthew Rimmer, 'The Global Tobacco Epidemic, the Plain Packaging of Tobacco Products, and the World Trade Organization' (2017) 17(2) Queensland University of Technology Law Review 131.

19 Tobacco Free Ireland (Report of the Tobacco Policy Review Group, Dublin 2013).

20 Protection of Children's Health (Tobacco Smoke in Mechanically Propelled Vehicles) Act 2014.

21 Directive 2014/40/EU of the European Parliament and of the Council of 3 April 2014 on the Approximation of the Laws, Regulations and Administrative Provisions of the Member States Concerning the Manufacture, Presentation and Sale of Tobacco and Related Products ((2014) OJ L 127). It repealed and replaced Directive 2001/37/EC, mentioned in n 17 above, and is in part directed to implementing the WHO Framework Convention mentioned in $\mathrm{n} 18$ above. It is given further effect in Irish law by the European Union (Manufacture, Presentation and Sale of Tobacco and Related Products) Regulations 2016 (SI 271/2016) and the European Union (Manufacture, Presentation and Sale of Tobacco and Related Products) (Amendment) Regulations 2017 (SI 252/2017).

Further legislative restrictions are planned: a Public Health (Sale of Tobacco Products and Electronic Nicotine Delivery Systems) Bill - to prohibit the sale of tobacco products, inter alia from self-service vending services and to persons under 18 years of age; and to license the retail sales of tobacco products and nicotine delivery systems - is promised in the government's Legislation Programme, Spring/Summer Session 2018 (Office of the Government Chief Whip 2018) <https://merrionstreet.ie/en/ImageLibrary/Legislative_Programme_Spring_Summer_2018.pdf>. 
In many respects, therefore, Ireland has been a world leader in tobacco control, from banning smoking in the workplace or in cars with children, to requiring standardised packaging. However, all of this has been in the teeth of intense opposition from the tobacco industry, which had fiercely opposed standardised packaging legislation, to the point of threatening to seek an injunction to prevent the Oireachtas from enacting the Bill that became the 2015 Act. ${ }^{22}$ Article 26 of the Constitution provides a procedure by which the President may refer a Bill to the Supreme Court for an assessment of its constitutionality; ${ }^{23}$ but, notwithstanding this controversy, it does not seem to have been suggested that this procedure might have been invoked. In the event, although the tobacco industry did not seek an injunction against the Bill, nevertheless, no sooner than the ink was dry on the President's signature, on 30 March 2015, the industry issued proceedings seeking declarations that the 2015 Act was contrary to European Union (EU) law. A reference to the Court of Justice of the EU was refused, and the case subsequently settled. ${ }^{24}$

At present, the EU law arguments are the tobacco industry's chosen battleground, but the Irish Constitution also provides some potential ammunition. When the Bill that became the 2015 Act was being considered by parliamentary committee, ${ }^{25}$ the probability of a constitutional challenge was a theme of submissions, not only from the tobacco industry, ${ }^{26}$ but also from the Law Society of Ireland. ${ }^{27}$ The subsequent legal challenge concentrated on the EU issues rather than constitutional considerations. Nevertheless, the possibility of a constitutional challenge cannot be excluded, ${ }^{28}$ and so it is to the

22 Arthur Beesley, 'Tobacco Giant Issues Legal Threat over Plain Packaging' Irish Times (Dublin, 17 February 2015); Arthur Beesley, 'Japan Tobacco's Packaging Objections Look Set for Courts' Irish Times (Dublin, 18 February 2015); Harry McGee, 'Government Prepared for Lawsuit as Tobacco Bill Passed' Irish Times (Dublin, 3 March 2015); Niall O’Connor, 'Tobacco Giants Threaten to “Undermine” Ireland's Economy in an Attempt to Block Plain-packaging Laws' Irish Independent (Dublin, 11 August 2017); 'Big Tobacco, Big Legal Threats' Phoenix Magazine (Dublin, 7 September 2017).

23 There have been 15 such references since the enactment of the Constitution in 1937; see <www.supremecourt.ie/supremecourt/sclibrary3.nsf/pagecurrent/5A270AE31790620C802575EB003DAC2C>.

24 In JTI Ireland Ltd v Minster for Health [2015] IEHC 481 (7 July 2015) Cregan J declined to make the reference, in part because precisely the same question had already been referred from the UK by Turner $J$ in $\mathrm{R}$ (Philip Morris Brands Sarl) v Secretary of State for Health [2014] EWHC 3669 (Admin) (7 November 2014). On that reference, in Case C 547/14 R (Philip Morris Brands Sarl) v Secretary of State for Health (ECLI:EU:C:2016:325; CJEU, 4 May 2016), the CJEU held that member states are permitted to set packaging standards beyond those harmonised by Directive 2014/40/EU (n 21 above). In the UK, those additional standards are set out in the Standardised Packaging of Tobacco Products Regulations 2015 (SI 829/2015) (see n 5 above), the validity of which was upheld by Green $J$ and the Court of Appeal in British American Tobacco v Secretary of State for Health [2016] EWHC 1169 (Admin) (19 May 2016) affd [2016] EWCA Civ 1182 (30 November 2016) (hereafter: $B A T)$; see, generally, Jonathan Griffiths, 'The Tobacco Industry's Challenge to the United Kingdom's Standardised Packaging Legislation - Global Lessons for Tobacco Control Policy?' (2017) 17(2) Queensland University of Technology Law Review 66. JTI Ireland Ltd v Minster for Health was settled after a directions hearing on 9 November 2016.

25 See Debates of the Joint Committee on Health and Children (13 February 2014), available at $<$ https://www.oireachtas.ie/en/debates/debate/joint_committee_on_health_and_children/2014-02-13/2/>.

26 Company Submissions by the Irish Tobacco Manufacturers' Advisory Committee, available at <www.itmac.ie/company-submissions>; see also Written Submissions on behalf of Philip Morris International, available at <http://health.gov.ie/wp-content/uploads/2014/07/Philip-Morris-i.pdf >.

27 See e.g. the opening remarks of the President of the Law Society of Ireland to the Joint Oireachtas Committee on Health and Children, 13 February 2014, available at <www.lawsociety.ie/globalassets/documents/ news/2014/opening-statement-plain-packaging--law-soc.pdf $>$ and <https://www.oireachtas.ie/en/debates/ debate/joint_committee_on_health_and_children/2014-02-13/2/>.

28 Perhaps the tobacco companies were waiting for the conclusion of their EU law case (see $\mathrm{n} 24$ above); or perhaps they were keeping their powder dry for this battle until the detailed implementation of the packaging legislation became clear. 
possible constitutional issues implicated by the packaging legislation that the analysis in this article is directed.

Part 2 of this article, on restrictions, describes the restrictions in the packaging legislation. Some packaging is prohibited, some is regulated and some is required; moreover, and in particular, there will be strict regulations upon, perhaps even prohibitions of, the use of trade marks and other branding.

Part 3 of this article, on rights, provides a conspectus of the Irish constitutional speech rights ${ }^{29}$ engaged or burdened by these restrictions. In particular, prohibitions upon, and regulation of, what can be said in packaging and branding, are potential restrictions upon the tobacco companies' constitutional speech rights, in particular in the commercial context. In PJ Carrolls v Minister for Health and Children, ${ }^{30}$ constitutional speech rights were one plank of the tobacco industry's challenge to tobacco advertising prohibitions in the Public Health (Tobacco) Act 2002, and they would be equally central to any challenge to the packaging legislation. This part therefore considers the speech authorities; it presents them as comprising a freedom of political expression in Article 40.6.1 of the Constitution and a freedom of autonomous communication in Article 40.3.1; $;^{31}$ and it considers the extent to which either freedom is likely to be engaged or burdened by prohibitions upon, and regulation of, the tobacco companies' commercial speech. Moreover, these two rights carry concomitant rights to keep silent and to be informed. Part 3 therefore also considers the extent to which the tobacco companies' rights to keep silent are likely to be engaged or burdened by required speech on tobacco packaging, and the extent to which the tobacco companies' customers' rights to be informed are likely to be engaged or burdened by all of the restrictions in the packaging legislation.

Part 4 of this article, on reasons, considers the pressing and substantial reasons which the state may proffer to seek to justify the restrictions in the packaging legislation upon constitutional speech rights. The state's interest in the promotion of public health was central to meeting the challenge in Carrolls, and it would be equally central to meeting any challenge to the packaging legislation. So too would be the protection of children. These

29 Gerard Hogan and Gerry Whyte, Kelly's the Irish Constitution (4th edn, LexisNexis Butterworths, Dublin 2003) (hereafter: Kelly) ch 7.5.II.

30 [2003] IEHC 613 (17 January 2003) (Kelly J) (discovery motions); [2004] IEHC 310 (29 July 2004) (Kelly J) (inadmissibility of expert evidence) rvsd [2005] IESC 26 (03 May 2005) (evidence admissible; courts do not interpret statutes in a vacuum) (hereafter: Carrolls). The case was settled after a pre-trial conference before Kelly J on 31 January 2007, and the order was perfected on 6 June 2007.

Regulations on the use to which the property in the packaging can be put and restrictions on the use of trade marks are also potential restrictions upon constitutional property rights. Those rights also featured in Carrolls, and they have been the main ground of challenge in the UK (see n 24 above) and Australia (JT International SA v Commonwealth of Australia (2012) 250 CLR 1, [2012] HCA 43 (5 October 2012) [hereafter: JTT]); see generally Tania Voon, 'Acquisition of Intellectual Property Rights: Australia's Plain Tobacco Packaging Dispute' (2013) 2 European Intellectual Property Review 113; Sam Ricketson, 'Plain Packaging Legislation for Tobacco Products and Trade Marks in the High Court of Australia' (2013) 3 Queen Mary Journal of Intellectual Property 224; Daniel Fletcher, 'JT International SAv Commonwealth: Tobacco Plain Packaging' (2013) 35 Sydney Law Review 827; Matthew Rimmer, 'The High Court of Australia and the Marlboro Man: The Battle over the Plain Packaging of Tobacco Products' in Voon et al (n 8) 337; Catherine Bond, 'Tobacco Plain Packaging in Australia: JT International v Commonwealth and Beyond' (2017) 17(2) Queensland University of Technology Law Review 1. On this issue under the European Convention on Human Rights and the Charter of Fundamental Rights of the EU, see Jonathan Griffiths, "On the Back of a Cigarette Packet" Standardised Packaging Legislation and the Tobacco Industry's Fundamental Right to (Intellectual) Property' [2015] Intellectual Property Quarterly 343.

On this issue at Irish law, see, generally, Eoin O’Dell, 'Property and Proportionality: Evaluating Ireland's Tobacco Packaging Legislation’ (2017) 17(2) Queensland University of Technology Law Review 46.

31 The full text of these Articles is set out in an Appendix below (see page 211). 
concerns have been relied upon to sustain important legislation in the past; this part considers the relevant authorities; and it analyses the extent to which they may be relied upon by the state to seek to justify the restrictions in the packaging legislation.

Part 5 of this article, on standards of review, considers the extent to which the restrictions in the packaging legislation, motivated by concerns relating to public health and the protection of children, satisfy the current Irish version of the principle of proportionality. It also considers the extent to which the restrictions might satisfy other standards of review or scrutiny.

Part 6 concludes this article. It brings together of all the strands of analysis in the previous parts. And it concludes that, if the restrictions on constitutional speech rights in the Public Health (Standardised Packaging of Tobacco) Act 2015 and in part 5 of the Health (Miscellaneous Provisions) Act 2017 are challenged by the tobacco companies, the courts will find that those Acts are constitutionally valid.

\section{Restrictions}

The packaging legislation deals with the packaging of cigarettes, roll-your-own tobacco, and other tobacco products, in practically identical terms; ${ }^{32}$ and the restrictions are broadly of three kinds - some elements of packaging are prohibited, others are regulated and still others are required.

\subsection{Prohibited packaging}

Those elements of packaging that are prohibited by the legislation include decorative ridges, embossing or other embellishments, coloured adhesive, and items inserted in or affixed to the packaging. ${ }^{33}$ Similarly prohibited on wrappers are colours, decorative ridges, embossing or other embellishments, branding and trade marks, and items affixed to the wrappers. ${ }^{34}$ Barcodes are prohibited from conveying any information to the consumer. ${ }^{35}$ Marks which are necessary for the automated manufacture of the packaging are prohibited from conveying any information to the consumer. ${ }^{36}$ And tobacco packing is prohibited from promoting tobacco consumption. ${ }^{37}$

\subsection{Regulated PaCKaging}

Those elements of packaging that are regulated by the Act include: the inks used; ${ }^{38}$ the colour of linings; ${ }^{39}$ the colour, dimensions, specifications and positioning of barcodes 40 and tear-strips; ${ }^{41}$ the colour, font type, font size, positioning and appearance of

32 See s 7 (retail packaging of cigarettes), s 9 (retail packaging of roll-your-own tobacco) and s 10 (retail packaging of other tobacco products) of the 2015 Act, as amended by ss 13-15 of the 2017 Act.

33 Ss 7(1)(d)-(f), 9(1)(d)-(f) and 10(1)(d)-(f) 2015 Act. Ss 9(4C) and 10(4C) of the 2015 Act, inserted by ss 14(d) and 15 (d) of the 2017 Act, permit plain re-sealing tabs for roll-your-own tobacco pouches and packaging of other tobacco products, provided that the tabs are transparent, uncoloured and unmarked, and do not have decorative ridges, embossing or other embellishments.

34 Ss 7(8)(b)-(e), 9(8)(b)-(e) and 10(7)(b)-(e) of the 2015 Act.

35 Ss 7(5), 9(5) and 10(5) of the 2015 Act, as implemented by reg 14 of the 2017 Regulations.

36 See ss 7(4B)(b), 9(4B)(b) and 10(4B)(b) of the 2015 Act, inserted respectively by ss 13(d), 14(d) and 15(d) of the 2017 Act.

37 See s 13 of the 2015 Act, as amended by s 16 of the 2017 Act.

38 S 14(b)(i)-(iii) of the 2015 Act.

39 S 11 of the 2015 Act, as implemented by reg 16 of the 2017 Regulations.

40 Ss 7(5), 9(5) and 10(5) of the 2015 Act, as implemented by reg 14 of the 2017 Regulations.

41 Ss 7(8)(d), 7(9), 9(8)(d), 9(9),10(7)(d) and 10(8) of the 2015 Act, as implemented by reg 15 of the 2017 Regulations. 
branding; ${ }^{42}$ and the location of brand names. ${ }^{43}$ This enabled the minister to make regulations ${ }^{44}$ requiring that all of these matters be presented in a standardised fashion by every brand on the market.

Moreover, tobacco packaging shall 'not bear a mark or trade mark' except as permitted pursuant to the 2015 Act. ${ }^{45}$ The general powers relating to the regulation of packing, and the specific rules relating to trade marks, will certainly control the use of trade marks upon - and potentially even effectively ban trade marks from - tobacco packing.

Furthermore, the Act emphasises that any permitted brand names cannot obscure or interfere with health warnings on cigarette packets. ${ }^{46}$ The Act also regulates the appearance of individual cigarettes. ${ }^{47}$

In prescribing the colours of sections of packaging, and in regulating branding, the minister is required to have regard to the need to decrease the appeal of tobacco products, to increase the effectiveness of health warnings, and to reduce the ability of packaging to mislead consumers about the harmful effects of smoking. ${ }^{48}$

\subsection{REQUIRED PACKAGING}

Finally, those elements of packaging that are required by the Act include: the colours of the sections of packaging; ${ }^{49}$ the shape of packets; ${ }^{50}$ and the transparency of wrappers. ${ }^{51}$

42 Ss 7(3)-(4), 7(10)-(11), 9(3)-(4), 9(10)-(11), 10(3)-(4) and 10(9)-(10) of the 2015 Act, as implemented by regs $9-12$ of the 2017 Regulations.

43 Ss 7(3)-(4), 9(3)-(4) and 10(3)-(4) of the 2015 Act, as extended by ss 13-15 of the 2017 Act, as implemented by reg 7 of the 2017 Regulations.

44 Ss 3, 7(10)-(11), 9(10)-(11) and 10(9)-(10) of the 2015 Act, as implemented by the 2017 Regulations, passim.

45 Ss 7(1)(c), 7(8)(d), 9(1)(c), 9(8)(d), 10(1)(c) and 10(7)(d) of the 2015 Act. However, these restrictions or prohibitions upon the use of trade marks in packaging cannot go so far as to prohibit the registration of a trade mark or provide grounds for the revocation a trade mark (see s 5(1)).

46 Ss 7(4), 9(4) and 10(4) of the 2015 Act. Regulations relating to the size and location of health warnings are provided by the EU (Manufacture, Presentation and Sale of Tobacco and Related Products) Regulations 2016 (SI 271/2016), implementing the Act and Directive 2014/40/EU (see n 21 above). To the extent that the Directive is valid (see n 24 above), then the statutory instrument implementing it, as a measure 'necessitated by the obligations of membership' of the EU, is immune from constitutional challenge (Article 29.4.6 of the Constitution; see Lawlor v Minister for Agriculture [1990] 1 IR 356, [1988] ILRM 400 (SC); Meagher v Minister for Agriculture [1994] 1 IR 329 (SC); Maher v Minister for Agriculture, Food and Rural Development [2001] 2 IR 139, [2001] 2 ILRM 481, [2001] IESC 32 (30 March 2001); Browne v Attorney General [2003] 3 IR 205, [2003] IESC 43 (16 July 2003); Quinn v Ireland (No 2) [2007] 3 IR 395, [2007] 2 ILRM 101, [2007] IESC 16 (29 March 2007)). Consequently, the regulations relating to health warnings are not considered further in this article.

47 S 8 of the 2015 Act, as implemented by reg 8 of the 2017 Regulations.

48 Ss 7(11), 9(11) and 10(10) of the 2015 Act; compare s 8(3).

49 Ss 7(1)(a)-(b), 9(1)(a)-(b) and 10(1)(a)-(b) of the 2015 Act, as implemented by regs 5 and 6 of the 2017 Regulations, prescribing 'Pantone reference 448C', which has been dubbed the world's ugliest colour; see Laura Slattery, 'How Sludgy Olive Green Became the Official Colour of Cigarettes' Irish Times (Dublin, 27 May 2016). This follows the Australian example (see reg 2.2.1(2) of the Tobacco Plain Packaging Regulations 2011 (Cth) (SLI 263/2011); 'Market Research to Determine Effective Plain Packaging of Tobacco Products' (Department of Health, Government of Australia, 18 June 2012) <www.health.gov.au/internet/publications/publishing.nsf/Content/mr-plainpack-mr-tob-products>. Pantone $448 \mathrm{C}$ has also been adopted in the UK (see reg 3(2) of the Standardised Packaging of Tobacco Products Regulations 2015 (SI 829/2015)).

50 Ss $7(6)$ and $9(6)$ of the 2015 Act. Whilst it is feasible to control the shape of boxes of cigarettes (s 7(6)) and of pouches of roll-your-own tobacco (s $9(6)$ ), the scores of other tobacco products come in so many shapes and sizes that it would be infeasible to seek to control of the shape of all of their packets. Hence, there is no equivalent sub-s in s 10; and this is the only real difference between the three sections.

51 Ss 7(8)(a), 9(8)(a) and 10(7)(a) of the 2015 Act. 
The prohibitions, regulations and requirements relating to packaging in the packaging legislation therefore take their place alongside the extensive rules on health warnings, 52 the comprehensive ban on advertising and sponsorship, and the strict regulation of sales that are provided in other legislation. ${ }^{3}$ This wide-ranging suite of reforms gives effect to government policy to reduce smoking and its harmful effects and to move Ireland towards a tobacco-free society. ${ }^{54}$

\section{Rights}

Since these prohibitions, regulations and requirements relating to packaging in the packaging legislation are all restrictions on what tobacco companies can say on the packets of their products, they certainly engage the rights in the Irish Constitution relating to speech, expression and communication. ${ }^{55}$

\subsection{FreEdom OF SPEECH}

In Ireland, two Articles of the Constitution are concerned with the protection of freedom of speech ${ }^{56}$ - Article 40.6.1(i) and Article 40.3.1. The right 'to express freely ... convictions and opinions' contained in Article 40.6.1(i) of the Constitution is a freedom of political expression, concerned with the public activities of the citizen in a democratic society. ${ }^{57} \mathrm{An}$ unenumerated right to communicate, implied in Article 40.3.1 ${ }^{58}$ as one of the most basic of human rights, is a freedom of autonomous communication concerned with conveying one's needs and emotions by words or gestures, as well as by rational discourse. ${ }^{59}$ Both are likely to be implicated in any consideration of the constitutionality of the packaging legislation.

\subsection{Political eXPREsSION}

Article 40.6.1(i) has been relied upon to strike down legislation on three occasions (though none is entirely unambiguous). In the final stage of Dunnes Stores $v$ Ryan, ${ }^{60}$

52 See $n 46$ above.

53 See nn 10-21 above.

54 As to the effectiveness of standardised packaging as an element of that strategy, see part 4.2 below.

55 This has been the chosen battleground in the USA and Canada. On the USA, see e.g. Lorillard Tobacco Co $v$ Reilly 533 US 525 (2001); RJ Reynolds Tobacco Co v United States Food and Drugs Administration 696 F3d 1205 (DC Cir, 2012); n 123 below. On Canada, see e.g. RJR-MacDonald Inc v Canada (Attorney General) [1995] 3 SCR 199, 1995 CanLII 64 (SCC) (21 August 1995); Canada (Attorney General) v JTI-Macdonald Corp [2007] 2 SCR 610, 2007 SCC 30 (CanLII) (28 June 2007).

56 Irish Times v Ireland [1998] 1 IR 359, [1998] 2 ILRM 161; Murphy v Irish Radio and Television Commission [1999] 1 IR 12, [1998] 2 ILRM 360; Holland v Governor of Portlaoise Prison [2004] 2 IR 573, [2004] IEHC 97 (11 June 2004); Mahon v Post Publications [2007] 3 IR 338, [2007] 2 ILRM 1, [2007] IESC 15 (29 March 2007); Kivlehan v Radio Teilifís Éireann [2016] IEHC 88 (15 February 2016).

57 Murphy $v$ Irish Radio and Television Commission [1999] 1 IR 12, 24-5, [1998] 2 ILRM 360, 372 (Barrington J; Hamilton CJ, O'Flaherty, Denham, and Keane JJ concurring).

58 On the identification and location of unenumerated rights in Article 40.3.1, see Ryan v Attorney General [1965] IR 294; Fleming $v$ Ireland [2013] 2 IR 417, 444-8, [2013] IESC 19, [109]-[115] (Denham CJ, for the court); Gerard Hogan, 'Unenumerated Personal Rights. Ryan's Case Re-evaluated' (1990-1992) 25-7 Irish Jurist (ns) 95; Desmond Clarke, 'Unenumerated Rights in Constitutional Law' (2011) 34 Dublin University Law Journal (ns) 101; David Kenny, 'Recent Developments in the Right of the Person in Article 40.3: Fleming v Ireland and the Spectre of Unenumerated Rights' (2011) 34 Dublin University Law Journal (ns) 101; Gerard Hogan, 'Unenumerated Personal Rights: the Legacy of Ryan v Attorney General in Laura Cahillane, James Gallen and Tom Hickey (eds), Judges, Politics and the Irish Constitution (Manchester University Press 2017) ch 4.

59 Murphy $v$ Irish Radio and Television Commission [1999] 1 IR 12, 24-5, [1998] 2 ILRM 360, 372 (Barrington J; Hamilton CJ, O'Flaherty, Denham, and Keane JJ concurring).

60 [2002] 2 IR 60 (HC; Kearns J); see [2002] IEHC 61 (5 June 2002), striking down s 19(6) of the Companies Act 1990, on the grounds that it infringed either the right to trial in due course of law in Article 38 or the right to silence implied into Article 40.6.1(i) (on which see nn 62, 69, 76, 86, 96-8, 123 and 151 below). 
Kearns $J$ in the High Court struck down a provision requiring a company or its officers to provide an explanation or make a statement to an officer making inquiries about the company. In Dillon $v$ DPP ${ }^{61}$ de Valera $\mathrm{J}$ in the High Court struck down a vague statutory restriction upon begging. And in Sweeny $v$ Ireland, ${ }^{62}$ Baker J struck down a wide statutory offence of withholding material information from Gardaí.

Article 40.6.1(i) has been successfully invoked in other ways on (at least) 20 further occasions: six times to shape the application of common law or equitable doctrines; ${ }^{63}$ four times to justify the protection of journalists' sources; ${ }^{64}$ twice to support the exercise of democratic speech; ${ }^{65}$ twice to constrain the interpretation of a statute; ${ }^{66}$ twice in

61 [2007] IEHC 480 (4 December 2007), striking down s 3 of the Vagrancy (Ireland) Act 1847 on the grounds that it infringed various provisions of the Constitution, including Article 40.6.1(i) (compare Coleman v Power (2004) 220 CLR 1, [2004] HCA 39 (1 September 2004)). However, the best explanation of the case is probably that the section was unconstitutionally vague: see Douglas v DPP [2013] 1 IR 510, [2013] IEHC 343 (26 July 2013); McInerney and Curtis v DPP [2014] 1 IR 536, [2014] IEHC 181 (9 April 2014); Sweeny v Ireland [2017] IEHC 702 (23 November 2017); David Prendergast, 'Douglas v DPP and the Constitutional Requirement for Certainty in Criminal Law' (2013) 50 Irish Jurist (ns) 235; contrast Cox v DPP [2015] IEHC 642 (20 October 2015); McNamee v DPP [2016] IEHC 286 (12 May 2016) affd [2017] IECA 230 (25 July 2017)). On the offensiveness and vagueness arguments, compare Monis v The Queen (2013) 249 CLR 92, [2013] HCA 4 (27 February 2013) and Shreya Singhal v Union of India AIR 2015 SC 1523, 2015 SCC Online SC 248 (24 March 2105).

62 [2017] IEHC 702 (23 November 2017) striking down s 9(1)(b) of the Offences Against the State (Amendment) Act 1998 on the grounds that it infringed the right to silence derived from the right to freedom of expression in Article 40 ([39]-[43]). Baker J said that O'Flaherty J in Supreme Court in Heaney $v$ Ireland [1996] 1 IR 580, [1997] 1 ILRM 117 dealt with the right to silence as a corollary of freedom of expression 'by reference to Article 40.3.1', whereas he in fact dealt with it by reference to Article 40.6.1(i). Consequently, Baker J's judgment should be understood to refer to the latter Article and not to the former. On the right to silence, see generally n 60 above, and nn 69, 76, 86, 96-98, 123, and 151 below.

63 Attorney General for England and Wales v Brandon Book Publishers [1986] IR 597, [1987] ILRM 135 (breach of confidence); Hunter v Gerald Duckworth and Co Ltd [2003] IEHC 81 (31 July 2003) (qualified privilege); Mahon $v$ Post Publications [2007] 3 IR 338, [2007] 2 ILRM 1, [2007] IESC 15 (29 March 2007) (breach of confidence); Herrity v Associated Newspapers (Ireland) Ltd [2009] 1 IR 316, [2008] IEHC 249 (18 July 2008) (invasion of privacy); Hickey v Sunday Newspapers Ltd [2011] 1 IR 228, [2010] IEHC 349 (8 October 2010) (same); Leech v Independent Newspapers (Ireland) Ltd [2014] IESC 79 (19 December 2014) (defamation damages; but see $\mathrm{n} 79$ below).

Dawson and Sons v Irish Brokers' Association (Supreme Court, unreported, 27 February 1997) (defamation damages), M v Drury [1994] 2 IR 8, [1995] 1 ILRM 108 (O’Hanlon J) (invasion of privacy), Foley $v$ Sunday Newspapers Ltd [2005] IEHC 14 (28 January 2005) (Kelly J) (defamation, interlocutory injunction refused), Cogley v Radio Telifís Éireann [2005] 4 IR 79, [2005] IEHC 180 (8 June 2005) (Clarke J) (invasion of privacy, interlocutory injunction refused), Murray $v$ Newsgroup Newspapers Ltd [2011] 2 IR 156, [2010] IEHC 248 (18 June 2010) (Irvine J) (same), and the injunction denied McKillen v Times Newspapers Ltd [2013] IEHC 150 (30 March 2013) (breach of confidence) are probably further examples, but in none of them do the judges tie their rhetorical references to freedom of expression specifically to Article 40.6.1(i), though that is almost certainly what they had in mind.

64 Mahon Tribunal v Keena [2010] 1 IR 336, [2009] IESC 78 (26 November 2009); Cornec v Morrice [2012] 1 IR 804, [2012] IEHC 376 (18 September 2012); Boyle v Governor of St Patrick's Institution [2015] IEHC 410 (25 June 2015); Ryanair Ltd v Channel 4 Television Corporation [2017] IEHC 651 (5 October 2017); see, generally, Eoin Carolan, 'The Implication of Media Fragmentation and Contemporary Democratic Discourse for "Journalistic Privilege" and the Protection of Sources' (2013) 49(1) Irish Jurist (ns) 138; Eoin Carolan, 'Protecting Public Interest Reporting: What is the Future of Journalistic Privilege in Irish Law?' (2017) 57 Irish Jurist (ns) 187.

65 Hyland v Dundalk Racing (1999) Ltd [2014] IEHC 60 (19 February 2014) affd [2017] IECA 172 (1 June 2017) [122] (Finlay Geoghegan, Peart and Irvine JJ in a joint judgment); O’Brien v Financial Services Ombudsman [2014] IEHC 268 (7 May 2014).

66 Philpott v Irish Examiner Ltd [2016] IEHC 62 (8 February 2016) (s 33 of the Defamation Act 2009); Muwema v Facebook Ireland Ltd [2016] IEHC 519 (23 August 2016) (same). 
contempt proceedings; ${ }^{67}$ once to strike down a ban on prisoner correspondence; ${ }^{68}$ once to find that a criminal conviction was unsafe; ${ }^{69}$ and once to support the freedom of expression of a tribunal of inquiry. ${ }^{70}$

On the other hand, Article 40.6.1(i) has been unsuccessfully relied upon to challenge legislation on (at least) eight occasions. In State (Lynch) $v$ Cooney, ${ }^{71}$ the Supreme Court upheld the power of the minister to preclude from broadcast any matter that 'would be likely to promote, or incite to, crime or would tend to undermine the authority of the State'. In Murphy v Irish Radio and Television Commission, ${ }^{72}$ the Supreme Court upheld a ban on religious advertising. In Colgan v Independent Radio and Television Commission, the High Court upheld a similar ban on political advertising. ${ }^{73}$ In Melton Enterprises Ltd $v$ Censorship of Publications Board ${ }^{74}$ the Supreme Court upheld the power to prohibit the publication of indecent or obscene periodicals. And in Cooney v Minister for the Environment, ${ }^{75}$ the Supreme

67 Desmond v Glackin [1993] 3 IR 1; DPP v Independent News and Media plc [2017] IECA 333 (21 December 2017) [14], [20]-[21], [27]-[28], [40]-[41] (Hogan J; Finlay Geoghegan J concurring). Moreover, Cullen v Toibin [1984] ILRM 577 (SC) and DPP $v$ Independent Newspapers (Ireland) Ltd [2005] 2 ILRM 453, [2005] IEHC 128 (3 May 2005) are probably further examples, but the judges did not tie their rhetorical references to freedom of expression specifically to Article 40.6.1(i), though that is very likely what they had in mind.

68 Holland v Governor of Portlaoise Prison [2004] 2 IR 573, [2004] IEHC 97 (11 June 2004) (blanket refusal of prison governor to allow prisoner to communicate with media about his case amounted to unconstitutional 'total and absolute abolition’ ([2004] 2 IR 573, 603, [2004] IEHC 97 [47] (McKechnie J)) of prisoner's rights, including Article 40.6.1(i)).

69 In DPP $v$ Finnerty [1999] 4 IR 364, [1999] IESC 130 (17 June 1999), Keane CJ for the Supreme Court held that inferences drawn from the appellant's silence infringed the constitutionally guaranteed right to remain silent that has been implied into Article 40.6.1(i) as a corollary of the right to freedom of expression (see nn 60 and 62 above, and nn 76, 86, 96-8, 123 and 151 below). In People (DPP) v Coddington (Court of Criminal Appeal, unreported, 31 May 2001), People (DPP) v McCowan [2003] 4 IR 349 and People (DPP) v Bowes [2004] 4 IR 223, [2004] IECCA 44 (22 November 2004), Finnerty was followed, and inferences were held to infringe the right to silence, but that right was not expressly located in Article 40.6.1(i).

70 Desmond v Moriarty [2004] 1 IR 334, [2004] IESC 3 (20 January 2004) (free speech of respondent tribunal outweighed good name and privacy of applicant).

71 [1982] 1 IR 337, upholding s 31(1) of the Broadcasting Authority Act 1960; see David Gwynn Morgan, 'Section 31: The Broadcasting Ban' (1990-1992) 25-7 Irish Jurist (ns) 117; Gerard Hogan, 'The Demise of the Irish Broadcasting Ban' (1994) 1 European Public Law 69; Patrick Twomey, 'Freedom of Expression Talking About "the Troubles"” in Tim Murphy and Patrick Twomey (eds), Ireland's Evolving Constitution, 19371997: Collected Essays (Hart, Oxford 1998) ch 15.

72 [1999] 1 IR 12, [1998] 2 ILRM 360, upholding the ban on religious advertising in s 10(3) of the Radio and Television Act 1988. The European Court of Human Rights upheld that outcome in Murphy $v$ Ireland 44179/98 (2003) 38 EHRR 212, [2003] ECHR 352 (10 July 2003).

73 [2000] 2 IR 490, [1999] 1 ILRM 22, [1998] IEHC 117 (20 July 1998), upholding the ban on political advertising in s 10(3) of the Radio and Television Act 1988. The House of Lords reached a similar conclusion in $R$ (Animal Defenders International) v Secretary of State for Culture, Media and Sport [2008] AC 1312, [2008] UKHL 15 (12 March 2008). The European Court of Human Rights upheld that outcome in Animal Defenders International v UK 48876/08 (2013) 57 EHRR 21, [2013] ECHR 362 (22 April 2013). Contrast Australian Capital Television Pty v Commonwealth (1992) 177 CLR 106, [1992] HCA 45 (30 September 1992).

74 [2003] 3 IR 623, [2003] IESC 55 (4 November 2003), upholding s 9 of the Censorship of Publications Act 1946.

75 [2007] 1 IR 296, [2006] IESC 61 (13 November 2006) upholding s 46(5) of the Electoral Act 1992; compare Burdick v Takushi 504 US 428 (1992) (prohibition on write-in voting does not infringe the First Amendment); Timmons v Twin Cities Area New Party 520 US 351 (1997) (prohibition on a candidate from one political party from appearing on the ballot as an endorsed candidate for another party does not infringe the First Amendment). On the power to restrict speech in the electoral context, see Frederick Schauer and Richard Pildes, 'Electoral Exceptionalism and the First Amendment' (1999) 77 Texas Law Review 1803; Geoffrey Stone, 'Electoral Exceptionalism and the First Amendment: A Road Paved with Good Intentions' (2011) 35 New York University Review of Law and Social Change 665. 
Court upheld a requirement that general election candidates who are not members of registered political parties should be described on nomination and ballot papers as 'NonParty' (rather than 'independent') candidates. Furthermore, three statutory limitations on Article 40.6.1(i)'s concomitant right to silence have similarly survived. ${ }^{76}$

Article 40.6.1(i) has been unsuccessfully invoked on (at least) 13 further occasions. For example, notwithstanding countervailing constitutional speech considerations, three findings of contempt have been made; ${ }^{77}$ two injunctions restraining publication have been granted; ${ }^{78}$ one high defamation damages award has been upheld; ${ }^{79}$ and an attempt to shape the application of the common law defence of justification in a defamation action failed. 80

76 In Heaney v Ireland [1996] 1 IR 580, [1997] 1 ILRM 117, the Supreme Court upheld a requirement to account for movements in s 52 of the Offences Against the State Act 1939; the European Court of Human Rights disapproved of that outcome in Heaney and McGuinness v Ireland 34720/97 (2001) 33 EHRR 12, [2000] ECHR 684 (21 December 2000) and Quinn v Ireland 36887/97 [2000] ECHR 690 (21 December 2000). In Rockv Ireland [1997] 3 IR 484, [1998] 2 ILRM 35 the Supreme Court upheld provisions permitting inferences in ss 18 and 19 of the Criminal Justice Act 1984. In Re National Irish Bank Ltd (No 1) [1999] 3 IR 145, [1999] 1 ILRM 321, [1999] IESC 18 (21 January 1999) the Supreme Court upheld the duty to produce books and documents to a company inspector in s 10(1) of the Companies Act 1990. See generally Gerard Hogan, 'The Right to Silence after National Irish Bank and Finnerty' (1999) 21 Dublin University Law Journal (ns) 176; Donal O'Donnell, 'A Comparison of Article 6 of European Convention on Human Rights and the Due Process Requirements of the Constitution of Ireland' [2004] Judicial Studies Institute Journal 37; and see nn 60, 62 and 69 above, and nn 86, 96-8, 123 and 151 below.

77 Kelly v O'Neill [2000] 1 IR 354, [2000] 1 ILRM 507, [1999] IESC 81 (2 December 1999); Murphy v British Broadcasting Corporation [2005] 3 IR 336, [2004] IEHC 420 (21 December 2004); DPP v Independent Newspapers (Ireland) Ltd [2006] 1 IR 366, [2005] IEHC 353 (21 July 2005).

78 Evans v Carlyle [2008] IEHC 143 (8 May 2008); O’Brien v Radio Telefís Éireann [2015] IEHC 397 (21 May 2015) (and see the later stage of the proceedings [2015] IEHC 379 (12 June 2015)).

The injunctions restraining publication granted in X (an Infant) v Sunday Newspapers Ltd [2014] IEHC 696 (24 October 2014) (Gilligan J) (invasion of privacy) and McKillen v Times Newspapers Ltd [2013] IEHC 150 (30 March 2013), those against demonstrations granted in Marine Terminals Ltd v Loughman [2009] IEHC 620 (15 September 2009), and the discovery order granted, notwithstanding journalistic privilege, in Walsh $v$ News Group Newspapers Ltd [2012] 3 IR 136, [2012] IEHC 353 (10 August 2012) are probably further examples, but the judges did not tie their rhetorical references to freedom of expression to Article 40.6.1(i), though that is almost certainly what they had in mind. See also $n 83$ below.

79 de Rossa v Independent Newspapers [1999] 4 IR 432, [1999] IESC 63 (30 July 1999). The European Court of Human Rights upheld that outcome in Independent News and Media v Ireland 55120/00 (2006) 42 EHRR 46, [2005] ECHR 402 (16 June 2005). However, although Leech v Independent Newspapers (Ireland) Ltd [2014] IESC 79 (19 December 2014) relied, inter alia, on constitutional considerations to reduce defamation damages (see n 63 above), in Independent Newspapers (Ireland) v Ireland 28199/15 [2017] ECHR 567 (15 June 2017) the European Court of Human Rights held that the damages in Leech were much higher than permitted by Independent News and Media (2005); and in McDonagh v Sunday Newspapers Ltd (No 2) [2017] IESC 59 (27 July 2017), the Supreme Court would have substantially reduced a defamation damages award, in part by reference to the European Court of Human Rights decision in Independent Newspapers (2017).

80 McDonagh v Sunday Newspapers Ltd (No 1) [2017] IESC 46 (28 June 2017). 
The Supreme Court has held that no right could constitutionally arise under Article 40.6.1(i) to obtain information for the purpose of defeating the constitutional right to life of the unborn child. ${ }^{81}$ The Article has not precluded a state post office monopoly, ${ }^{82}$ or statements by the Referendum Commission during the course of a referendum campaign, ${ }^{83}$ or an extradition to face charges relating to unlawful communications, ${ }^{84}$ and it did not require the participation of a political leader in a television debate. ${ }^{85}$ Finally, the right to silence in criminal cases also located in Article 40.6.1(i) is not infringed by the practical necessity to file an affidavit in a linked civil case. ${ }^{86}$

81 Attorney General (Society for the Protection of the Unborn Child) v Open Door Counselling [1988] IR 593, 625 (Finlay CJ) affirming [1988] IR 593, 617 (Hamilton P); James Friedman, 'On the Dangers of Moral Certainty and Sacred Trusts' (1988) 10 Dublin University Law Journal (ns) 71. The European Court of Human Rights disapproved of that outcome in Open Door and Dublin Well Woman v Ireland 14234/88 and 14235/88 (1993) 15 EHRR 244, [1992] ECHR 68 (29 October 1992). Nevertheless, the Supreme Court followed its own decision here in Society for the Protection of Unborn Children v Grogan [1989] IR 753, 764 (Finlay CJ), Re Article 26 and the Regulation of Information (Services outside the State for the Termination of Pregnancies) Bill 1995 [1995] 1 IR 1, 28-31, [1995] IESC 9 (12 May 1995) (Hamilton CJ) and Society for the Protection of Unborn Children v Grogan (No 5) [1998] 4 IR 343, 361-2 (Hamilton CJ). The right to life of the unborn child had been inserted into Article 40.3 .3 of the Constitution by the Eighth Amendment in 1983 (see Attorney General v X [1992] 1 IR 1, [1992] ILRM 401, [1992] IESC 1 (5 March 1992)), but it was subsequently amended by the Fourteenth Amendment in 1995, to include a freedom to provide information relating to services lawfully available in another state. In Grogan (No 5), the Supreme Court affirmed that Open Door Counselling was correctly decided having regard to the terms of the Eighth Amendment, but it also held that its prohibition had to be modified in the light of the Fourteenth Amendment. However, Article 40.6.1(i) does not feature in any of these subsequent cases.

82 Attorney General v Paperlink [1984] ILRM 373, [1983] IEHC 1 (15 July 1983); see Gerard McCormack, 'Constitutional Law - Monopoly Power in the High Court' (1984) 6 Dublin University Law Journal (ns) 144.

83 Doherty $v$ the Referendum Commission [2012] IEHC 211 (6 June 2012) (process of robust political debate from an informed public not infringed by respondent's statements); indeed, though it was not argued in the case, the proper role of Article 40.6.1(i) would have been to support the respondent's statements (compare Desmond $v$ Moriarty (n 70 above)). Similarly, the 'freedom to express opinions incorporates the corollary right that in the democratic process of free elections, public funds should not be used to fund one side of an electoral process, whether it be a referendum or a general election, to the detriment of the other side of the argument' (McKenna $v$ An Taoiseach (No 2) [1995] 2 IR 10, 53, [1995] IESC 11 (17 November 1995) (Denham J); see also Hanafin v Minister for the Environment [1996] 2 IR 321, 448, [1996] 2 ILRM 161, 204, [1996] IESC 6 (12 June 1996) (Denham J); McCrystal v Minister for Children and Youth Affairs [2012] 2 IR 726, 754-755, 766, [2013] I ILRM 217, 237, 246, [2012] IESC 53 (8 November 2012), [37](viii)-(ix), [77](viii)-(ix) (Denham CJ); Jordan v Minister for Children and Youth Affairs [2015] 4 IR 232, 266, [2015] IESC 33 (24 April 2015), [129] (Denham CJ)). As with the judges referred to in $\mathrm{n} 78$ above, Denham CJ did not tie her references to freedom of expression in these cases to Article 40.6.1(i), though that is almost certainly what she had in mind. To the extent that it is, then these cases lend support both to the political expression reading of that Article (see e.g. nn 57 and 65 above, and $\mathrm{n} 95$ below) and to the derivation of corollary rights from it (see e.g. nn 98-99 below).

84 Minister for Justice, Equality and Law Reform v Hill [2009] IEHC 159 (3 April 2009) (no infringement of Article 40.6.1(i) by extradition to face charges relating to communications to a trial judge and jury foreman to influence the outcome of a trial).

85 Kivlehan v Radio Teilifís Éireann [2016] IEHC 88 (15 February 2016) (Article 40.6.1(i), among other constitutional provisions, informed the interpretation of ss 39, 42 and 114 of the Broadcasting Act 2009).

86 Wicklow County Council v O’Reilly Brownfield Restoration Ireland Ltd [2006] 3 IR 623, [2006] IEHC 273 (8 September 2006). Moreover, in People (DPP) v MK [2005] 3 IR 423, [2005] IECCA 93 (19 July 2005), DPP $v$ Bullman [2009] IECCA 84 (28 July 2009), DPP v Brian Kearney [2009] IECCA 112 (9 October 2009), DPP v White [2011] IECCA 78 (19 October 2011), DPP $v$ O'Shea [2014] IECCA 49 (27 November 2014) and DPP $v$ MacCarthaigh [2015] IECA 234 (3 November 2015), the decision of the Supreme Court in DPP v Finnerty [1999] 4 IR 364, [1999] IESC 130 (17 June 1999) (n 69 above) was followed, and inferences were held not to infringe the right to silence, but that right was not expressly located in Article 40.6.1(i). On that right to silence, see generally nn 60, 62, 69 and 76 above and nn 96-8, 123 and 151 below. 
There are some neutral references to Article 40.6.1(i) which are at best window dressing $; 87$ in particular, defamation cases are increasingly replete with comments stating the need to balance that right with the constitutional right to a good name in Article $40.3 .1,{ }^{88}$ but they have very little impact on the analysis or outcome. There are also some cases in which it has been held not to have been engaged or burdened on the facts. ${ }^{89}$

Although early cases took a narrow approach to Article 40.6.1(i), tending to focus on its weaknesses and limitations, ${ }^{90}$ the courts are now taking an increasingly expansive approach. If Homer can make the Iliad from a local row, ${ }^{91}$ and if the US Supreme Court can spell out the most luxuriant theories of free speech protections from the arid, thin soil of 14 words in the First Amendment, ${ }^{92}$ then the Irish courts can coax some growth from the stony, grey soil ${ }^{93}$ of Article 40.6.1(i). For example, though its protection is directed to 'convictions and opinions', the courts have held that it is not confined to them and also protects the right to express facts and information. ${ }^{94}$

On the other hand, the courts have not yet fully worked out the consequences of reading Article 40.6.1(i) as a freedom of political expression concerned with the public

87 In Irish Times $v$ Ireland [1998] 1 IR 359, [1998] 2 ILRM 161 (see n 94 below) it was very important window dressing, supporting the principle of open justice in Article 34.1 of the Constitution. In O'Brien v Mirror Group Newspapers Ltd [2000] IESC 70 (25 October 2000) the Supreme Court reduced a defamation damages award; in $K$ (A Minor) v Independent Star [2010] IEHC 500 (3 November 2010) Hedigan J held that the cause of action of invasion of privacy had not been established; in Desmond v Doyle [2013] IESC 59 (17 December 2013) the Supreme Court declined to dismiss defamation proceedings on the basis of delay; and, in all three cases, references to Article 40.6.1(i) made no difference to the outcome.

88 See e.g. Hynes-O’Sullivan v O'Driscoll [1988] IR 436, 450, [1989] ILRM 349, 361 (Henchy J); Foley v Independent Newspapers Ltd [1994] 2 ILRM 61, 67 (Geoghegan J); O'Brien (n 87); de Rossa v Independent Newspapers [1999] 4 IR 432, 456, [1999] IESC 63 (30 July 1999) (Hamilton CJ); Burke v Associated Newspapers (Ireland) Ltd [2010] IEHC 447 (10 December 2010), [32] (Hogan J); Leech v Independent Newspapers (Ireland) Ltd [2014] IESC 79 (19 December 2014) (Dunne J; Murray J concurring), [12], [58]-[59] (McKechnie J); Rooney v Shell E\& P Ireland Ltd [2017] IEHC 63 (20 January 2017), [31]-[32] (Ní Raifeartaigh J); Christie v TV3 Television Networks Ltd [2017] IECA 128 (4 May 2017), [33]-[35] (Hogan J; Peart and Irvine JJ concurring); McDonagh v Sunday Newspapers Ltd (No 2) [2017] IESC 59 (27 July 2017), [38]-[40] (O’Donnell J), [4] (Dunne J), [7] (MacMenamin J). See also Jones v Coolmore Stud [2017] IECA 164 (25 May 2017), [26], [36], [52] ((Ryan P; Irvine and Barr JJ concurring).

89 See e.g. Attorney General v Paperlink [1984] ILRM 373, 381, [1983] IEHC 1 (15 July 1983), [31] (Costello J); Oblique Financial Services Ltd v The Promise Production Co Ltd [1994] 1 ILRM 74, 78 (Keane J); Carrigaline Community Television Broadcasting Co Ltd v Minister for Transport, Energy and Communications [1997] 1 ILRM 241, 288 (Keane J). These cases have now been overtaken by the subsequent development of the freedom of political communication and its more expansive approach to Article 40.6.1(i); see e.g. n 94 below.

90 See the cases in the previous footnote; see also The State (Lynch) v Cooney [1982] 1 IR 337 (see n 71 above); Report of the Constitution Review Group (Pn 2632, Dublin, 1996) 291-2.

91 See 'Epic' by Patrick Kavanagh in Antoinette Quinn (ed), Patrick Kavanagh: Collected Poems (Penguin 2005$) 184$.

92 'Congress shall make no law . . . abridging the freedom of speech, or of the press ....

93 See 'Stony Grey Soil' by Kavanagh in Quinn (ed) (n 91) 38.

94 Irish Times $v$ Ireland [1998] 1 IR 359, 395, [1998] 2 ILRM 161, 181 (O’Flaherty J), [1998] 1 IR 359, 399 [1998] 2 ILRM 161, 185 (Denham J), [1998] 1 IR 359, 405, [1998] 2 ILRM 161, 193 (Barrington J); Murpby v Irish Radio and Television Commission [1999] 1 IR 12, 24-5, [1998] 2 ILRM 360, 372 (Barrington J; Hamilton CJ, O'Flaherty, Denham, and Keane JJ concurring); Mahon v Post Publications [2007] 3 IR 338, 377, [2007] 2 ILRM 1, 15-16, [2007] IESC 15 (29 March 2007), [51] (Fennelly J; Murray CJ and Denham J concurring). The contrary conclusion in the cases in $\mathrm{n} 89$ is no longer good law. For one view of the consequences of such an expansion, see Eoin O'Dell, 'Does Defamation Value Free Expression? The Possible Influence of New York Times v Sullivan on Irish Law' (1990) 12 Dublin University Law Journal (ns) 50. The German courts have adopted a similarly expansive interpretation of the constitutional protections of the expression of opinions in Article 5 Grundgesetz; see e.g. 93 BVerfGE 93, 266 (1 BvR 1476/91, First Senate, 10 October 1995) (Soldaten sind Mörder/Soldiers Are Murderers). 
activities of the citizen in a democratic society. ${ }^{95}$ In particular, deriving a right to silence as a concomitant of the right in Article 40.6.1(i) predates the emergence of a political speech reading of that right, ${ }^{96}$ and the two lines of authority are hard to reconcile - the right to silence is a matter of due process and criminal procedure, and it covers more than silence about political matters. It would therefore be best if the due process right to silence in criminal proceedings were to be located in (or relocated to) Article 38.1 of the Constitution, which protects trial in due course of law. ${ }^{97}$ The due process right to silence in criminal proceedings would have a more appropriate and secure constitutional location, and the freedom of political expression would be able to develop in a coherent fashion. In appropriate cases, it should support the derivation of a concomitant right to keep silent on political matters, ${ }^{98}$ as well as a concomitant right to be informed on political

95 Guidance on what counts as 'political' for these purposes might be found, for example, in Lange v Australian Broadcasting Corporation (1997) 189 CLR 520, [1997] HCA 25 (8 July 1997); Coleman v Power (2004) 220 CLR 1, [2004] HCA 39 (1 September 2004); Wotton v Queensland (2012) 246 CLR 1, [2012] HCA 2 (29 February 2012); Monis v The Queen (2013) 249 CLR 92, [2013] HCA 4 (27 February 2013); McCloy v New South Wales (2015) 257 CLR 178, [2015] HCA 34 (7 October 2015).

96 See nn 60, 62, 69, 76 and 86 above, and nn 123 and 151 below. The right to silence cases start in 1996 with Heaney $v$ Ireland [1996] 1 IR 580, [1997] 1 ILRM 117, whilst the political speech reading starts in 1998 with Irish Times v Ireland [1998] 1 IR 359, [1998] 2 ILRM 161 and Murphy v Irish Radio and Television Commission [1999] 1 IR 12, [1998] 2 ILRM 360.

97 This was the view of Costello J at first instance in Heaney [1994] 3 IR 593, 605-6, [1994] 2 ILRM 420, 42931. In Re National Irish Bank, both Shanley J at first instance ([1999] 3 IR 145, 156, [1999] 1 ILRM 321, 331, [1998] IEHC 116 (13 July 1998), [11]) and Barrington J on appeal ([1999] 3 IR 145, 187, 188, [1999] 1 ILRM 321, 359, 360, [1999] IESC 18 [53], [56] (21 January 1999) (Barrington J; O’Flaherty, Murphy, Lynch and Barron JJ concurring)) kept the door resolutely open to locating the right to silence in a criminal trial in Article 38.1 (see also Sweeny v Ireland [2017] IEHC 702 (23 November 2017), [40] (Baker J). In Dunnes Stores $v$ Ryan [2002] IEHC 61 (5 June 2002) Kearns J was studiedly ambiguous as to whether the right to silence which was infringed by s 19(6) of the Companies Act 1990 was located in Article 38 or Article 40.6.1(i). In DPP $v$ Roibu [2012] IEHC 421 (7 June 2012), [5.4] Hedigan J held that there was 'an interference with the appellant's right to silence which is protected under Article 38.1 of the Constitution'. In Donnelly v Judges of Dublin Metropolitan District Court [2015] IEHC 125 (3 March 2015), upholding the shifting of the evidential burden of proof in s 9(6) of the Firearms and Offensive Weapons Act 1990, Noonan J dealt with the right to silence in the context of Article 38.1 and made no reference to Article 40.6.1. In Redmond v Ireland [2015] IESC 98 (17 December 2015), [21] Charleton J (Denham CJ, Hardiman, McKechnie and MacMenamin JJ concurring) expressly approved of Costello J's approach to Article 38.1 in Heaney. In DPP $v$ McD [2016] IESC 71 (14 December 2016), [79] McKechnie J (Denham CJ, O’Donnell and O'Malley JJ concurring) held that the right to silence 'is firmly anchored' in Article 38.1, so that it was not necessary to say where in other circumstances the right can also be found, such as Article 40.3.1 or Article 40.6.1(i). In DPP $v$ M [2018] IESC 21 (21 March 2018), [37] O'Malley J (Clarke CJ and O'Donnell, Dunne and Charleton JJ concurring) held that, notwithstanding Heaney, the right to silence 'also belongs to the group of fair trial rights protected by Article 38' (emphasis added).

98 The Supreme Court has held that the right to associate in Article 40.6.1(iii) carries with it a correlative right to disassociate (Educational Company of Ireland v Fitzpatrick (No 2) [1961] IR 345 (SC); Meskell v Coras Iompair Éireann [1973] IR 121 (SC)). This was the basis on which O'Flaherty J in Heaney v Ireland [1996] 1 IR 580, 585, [1997] 1 ILRM 117, 123 derived the right to silence from Article 40.6.1(i). That right to silence should now be regarded as an element of due process secured by Article 38 (see nn 60, 62, 69, 76, and 96-7 above; see also nn 123 and 151 below). Nevertheless, a similar process of reasoning would derive a correlative right to keep silent on political matters from the recast Article 40.6.1(i) freedom of political expression. Compare West Virginia State Board of Education v Barnette 319 US 624 (1943) (right not to recite Pledge of Allegiance); Wooley v Maynard 430 US 705 (1977) (right not to display New Hampshire's state motto 'Live Free or Die' on licence plates); Pacific Gas and Electric Co v Public Utilities Commission of California 475 US 1 (1986) (right of utility to decline to carry third-party comments on bills' envelopes); Riley $v$ National Federation of the Blind of North Carolina 487 US 781 (1988) (right of professional fundraisers to refuse to disclose percentage of charitable contributions actually turned over to charity). 
matters. ${ }^{99}$ Finally, here, it is an open question of whether this freedom extends beyond political matters and, if so, how far it might go.

Against this background, two questions arise concerning the restrictions in the packaging legislation. First, do they in fact restrict the tobacco companies' speech? And second, if so, is the freedom of political expression in Article 40.6.1(i) engaged or burdened by these restrictions?

The restrictions in the packaging legislation do indeed restrict tobacco companies' speech, in four ways. First, the restrictions in the Act impose extensive prohibitions not only upon what tobacco companies may print on the packaging of their products, but also upon how they may present that packaging more generally, ${ }^{100}$ and these are plainly restrictions upon those companies' speech.

Second, the restrictions in the packaging legislation go further and contain significant regulations concerning not only what tobacco companies may print on the packaging of their products, but also how they may present that packaging more generally. ${ }^{101}$ To the extent that these regulations amount to prohibitions, then they too are plainly restrictions upon those companies' speech. And, to the extent that these regulations control what tobacco companies may print on and otherwise present the packaging of their products, they too amount to restrictions upon those companies' speech. These restrictions may be less than complete prohibitions upon their speech, but they are still restrictions all the same. ${ }^{102}$

Third, these regulations on packaging in the packaging legislation include controls on branding, which will certainly restrict - and, likely, ultimately ban - the use of trade marks from tobacco packing. ${ }^{103}$ To the extent that the use of the trade marks represents a specific example of the companies' speech, then the restrictions on the use of those trade marks would amount to a restriction on the companies' exercise of their speech rights. ${ }^{104}$

Fourth, the restrictions in the packaging legislation contain several elements of packaging that are required of the tobacco companies. ${ }^{105}$ These restrictions compel speech, and thus amount to restrictions upon the companies' right to keep silent on such matters.

Finally, some of these restrictions upon the companies' rights (in particular, the prohibitions upon what they can say) could also amount to restrictions upon the companies' customers' rights to be informed.

However, although restrictions in the packaging legislation do restrict tobacco companies' speech (and may also restrict their customers' rights), it is not clear how far, if at all, the freedom of political expression in Article 40.6.1(i) would be engaged or burdened by these restrictions. Since it is the usual port of call in speech cases, it would

99 In Cullen v Toibin [1984] ILRM 577, 582 McCarthy J mentioned that citizens have the right to be informed, but he did not tie this specifically to Article 40.6.1(i), though that is very likely what he had in mind. In Irish Times $v$ Ireland [1998] 1 IR 359, 405, [1998] 2 ILRM 161, 193, Barrington J approved this dictum during the course of his discussion of Article 40.6.1(i). In K (A Minor) v Independent Star [2010] IEHC 500 (3 November 2010), [83] Hedigan J commented that Article 40.6.1(i) includes the right to receive information.

100 See part 2.1 above.

101 See part 2.2 above.

102 The fact that a restriction upon a right is a regulation of the right rather than a complete prohibition upon it may make the restriction more proportionate or otherwise have an impact upon the review or scrutiny of the restriction, but it does not mean that the regulation is not a restriction; see part 5.2 below.

103 See nn 44-5 above.

104 Compare Matal v Tam 582 US _ (2017) (Alito J, for the court) (restrictions on registration of trade marks infringed First Amendment speech rights).

105 See part 2.3 above. 
almost certainly be invoked in any challenge to the packaging legislation. However, the expression restricted by that legislation is commercial rather than political in nature, and if the political reading of Article 40.6.1(i) is to be taken seriously, then the Article may not be engaged or burdened by the restrictions in the packaging legislation. Before the emergence of the political expression reading of the Article, there were some attempts to bring commercial speech within its reach, ${ }^{106}$ and there have been some suggestions that the language of some of the political speech cases does not entirely preclude this development, ${ }^{107}$ so it may be that commercial speech cases could drive the further expansion of the Article. But if they do not, then, to seek constitutional protection for commercial speech, ${ }^{108}$ analysis would have to turn to the second speech right in the Irish constitutional order - the freedom of autonomous communication in Article 40.3.1.

\subsection{AUTONOMOUS COMMUNICATION}

In Attorney General v Paperlink, Costello J held that, since the act of communication is the exercise of such a basic human faculty, 'a right to communicate must inhere in the citizen by virtue of his human personality and must be guaranteed by the Constitution ... [as] one of those personal unspecified rights of the citizen protected by Article 40.3.1'.109 In Dillon $v$ DPP, de Valera J struck down a vague statutory restriction upon begging, and he referred to the freedom of autonomous communication. ${ }^{110}$ Moreover, the freedom of autonomous communication in Article 40.3.1 has been successfully invoked in other ways on (at least) three further occasions: twice to strike down restrictions on prisoners' correspondence, ${ }^{111}$ and once to shape the application of the equitable doctrine of breach of confidence. ${ }^{112}$

On the other hand, Article 40.3.1 has been unsuccessfully relied upon to challenge legislation on three occasions. In Carrigaline Community Television Broadcasting Co Ltd v Minister for Transport, Energy and Communications, 113 Keane $\mathrm{J}$ in the High Court upheld key elements of the state's television broadcasting regime. In Murphy $v$ Irish Radio and Television

106 Gerard Quinn, 'The Right of Lawyers to Advertise in the Market for Legal Services: A Comparative American, European and Irish Perspective' (1991) 20 Anglo-American Law Review 403, 434-6; Gerard Quinn, 'Comparative Commercial Speech' in Liz Heffernan and James Kingston (eds), Human Rights: A European Perspective (Round Hall Press, Dublin 1994) ch 6.5.

107 Kelly [7.5.12] 1728; Ailbhe O’Neill, ‘Corporate Freedom of Expression' (2005) 27 Dublin University Law Journal (ns) 184, 191.

108 See, generally, Roger A Shiner, Freedom of Commercial Expression (Oxford University Press 2003); Victor Brudney, 'The First Amendment and Commercial Speech' (2012) 53 Boston College Law Review 1153; Joanna Krzeminska-Vamvaka, Freedom of Commercial Speech in Europe (Verlag Dr Kovač, Hamburg 2008).

109 Attorney General v Paperlink [1984] ILRM 373, 381, [1983] IEHC 1 (15 July 1983), [31]. In Holland v Governor of Portlaoise Prison [2004] 2 IR 573, [2004] IEHC 97 (11 June 2004), [20] McKechnie J noted that the right 'appears to have been accepted, rather than established' in The State (Murray) v Governor of Limerick Prison (High Court, unreported 23 August 1978), where Darcy J held that prison regulations restricting communications between a husband and wife who were both convicted prisoners did not render their respective detentions unlawful.

110 [2007] IEHC 480 (4 December 2007); however, the case probably turned on Article 40.6.1(i), and the best explanation is now probably that the section was unconstitutionally vague; see $\mathrm{n} 61$ above.

111 Kearney v Minister for Justice [1986] IR 116, [1987] ILRM 52; Holland v Governor of Portlaoise Prison [2004] 2 IR 573, [2004] IEHC 97 (11 June 2004) (blanket refusal of prison governor to allow prisoner to communicate with media about his case amounted to unconstitutional ‘total and absolute abolition' ([2004] 2 IR 573, 603, [2004] IEHC 97 [47] (McKechnie J)) of prisoner's rights, including the freedom of autonomous communication in Article 40.3.1).

112 Mahon v Post Publications [2007] 3 IR 338, [2007] 2 ILRM 1, [2007] IESC 15 (29 March 2007) (breach of confidence).

113 [1997] 1 ILRM 241, upholding ss 5 and 6 of the Wireless Telegraphy Act 1926 and s 17 of the Broadcasting and Wireless Telegraphy Act 1988. 
Commission, ${ }^{114}$ the Supreme Court upheld a ban on religious advertising. In Colgan v Independent Radio and Television Commission, ${ }^{115}$ the High Court upheld a similar ban on political advertising. And the Article has been unsuccessfully invoked in other ways on (at least) four further occasions. For example, the freedom of autonomous communication did not prevent the grant of two injunctions restraining publication, ${ }^{116}$ or require the participation of a political leader in a television debate. ${ }^{117}$ Moreover, in Paperlink itself, it did not preclude a state post office monopoly. ${ }^{118}$

It is one of the bases upon which the High Court granted leave to challenge the validity of the Irish and EU data retention regimes, but the full trial has not yet been heard. ${ }^{119}$ There are some neutral references to Article 40.3.1, which are at best window dressing; ${ }^{120}$ in particular, it has been referred to but not relied upon in several cases. ${ }^{121}$

The freedom of autonomous communication was implied into Article 40.3.1 as a response to a narrow approach to Article 40.6.1(i), ${ }^{122}$ but the courts have now committed to a stable pair of freedoms, and they are taking an increasingly expansive approach to both of them. Nevertheless, they have not yet fully worked out the consequences of innovating a basic right to communicate one's needs and emotions by words or gestures, as well as by rational discourse. Nevertheless, its foundations are sufficiently secure that it should be able to develop in a coherent fashion. In appropriate cases, it should support

114 [1999] 1 IR 12, [1998] 2 ILRM 360.

115 [2000] 2 IR 490, [1999] 1 ILRM 22, [1998] IEHC 117 (20 July 1998).

116 Oblique Financial Services Ltd v The Promise Production Co Ltd [1994] 1 ILRM 74; O’Brien v Radio Telefís Éireann [2015] IEHC 397 (21 May 2015).

117 Kivlehan v Radio Teilifís Éireann [2016] IEHC 88 (15 February 2016) (Article 40.3, among other constitutional provisions, informed the interpretation of ss 39, 42 and 114 of the Broadcasting Act 2009).

118 See nn 82, 89 and 109 above.

119 Digital Rights Ireland Ltd v Minister for Communications, Marine and Natural Resources [2010] 3 IR 251, [2010] IEHC 221 (5 May 2010). On a reference in that case to the Court of Justice of the EU, in Joined Cases C-293/12 and C-594/12 Digital Rights Ireland Ltd v Minister for Communications, Marine and Natural Resources and Seitlinger v Austria [2014] ECR I-238 (ECLI:EU:C:2014:238; CJEU, 8 April 2014) the CJEU struck down the Data Retention Directive (Directive 2006/24/EC of the European Parliament and of the Council of 15 March 2006 on the Retention of Data Generated or Processed in Connection with the Provision of Publicly Available Electronic Communications Services or of Public Communications Networks ((2006) OJ L 105)) on privacy grounds. When the matter returned to Austria, the Constitutional Court struck down the Austrian laws on data retention (G 47/2012 (Verfassungsgerichtshof, 27 June 2014)), also on privacy grounds. The matter has only recently been recommenced in the Irish High Court (in Digital Rights Ireland v Minister for Communications, Marine and Natural Resources [2017] IEHC 307 (19 July 2017) Costello J rejected an application for the trial of a preliminary issue) so the question of whether Irish data retention laws are constitutional on privacy or communication grounds has not yet been decided.

120 In Irish Times v Ireland [1998] 1 IR 359, [1998] 2 ILRM 161, it was important window dressing, supporting the principle of open justice in Article 34.1 of the Constitution. In Jonathan v Ireland [2002] IEHC 59 (31 May 2002) it was pleaded, but Murphy J dismissed the claim on the grounds of mootness.

121 In Hunter $v$ Gerald Duckworth and Co Ltd [2003] IEHC 81 (31 July 2003), Article 40.3.1 was mentioned but not relied upon by Ó Caoimh $\mathrm{J}$ in considering the impact of the Constitution on the defamation defence of qualified privilege. In Domican v Axa Insurance Ltd [2007] 2 IR 682, [2007] IEHC 14 (19 January 2007), it was mentioned but not relied upon by Clarke $\mathrm{J}$ in holding that the defendant insurer was entitled to copy its correspondence concerning the plaintiff's claim directly to the plaintiff notwithstanding his written instructions that all such correspondence should be addressed only to his solicitors. In Devoy $v$ Governor of Portlaoise Prison [2009] IEHC 288 (22 June 2009) it was mentioned but not relied upon by Edwards J in holding that a restriction on a prisoner's correspondence was ultra vires. In Mv Minister for Justice and Equality [2018] IESC 14 (7 March 2018), [10.41] it was referred to by Clarke CJ, and O'Donnell, McKechnie, MacMenamin, Dunne, O'Malley and Finlay Geoghegan JJ, in a joint judgment, as one of a list of unenumerated rights in Article 40.3.

122 See the cases cited in nn 89 and 94 above. 
the derivation of a concomitant right to keep silent, ${ }^{123}$ as well as a concomitant right to be informed. ${ }^{124}$

Against this background, two questions arise concerning the restrictions in the packaging legislation. First, do they in fact restrict the tobacco companies' speech? And second, if so, is the freedom of autonomous communication in Article 40.3.1 engaged or burdened by these restrictions?

The prohibitions upon, and regulations concerning, what tobacco companies may print on and otherwise present the packaging of their products are restrictions upon those companies' speech; requirements about packaging amount to restrictions upon the companies' right to keep silent on such matters; and these restrictions may also amount to restrictions upon the companies' customers' rights to be informed. It is very likely that the freedom of autonomous communication in Article 40.3.1 would be engaged or burdened by these restrictions. It would almost certainly be invoked in any challenge to the packaging legislation. Unlike with Article 40.6.1(i), the fact that the speech at issue here is commercial is less likely to bring it outside the ambit of Article 40.3.1. Although the essence of the right is that it is concerned with human personality, needs and emotions, ${ }^{125}$ nevertheless, in several cases, the courts have held that the right is engaged or burdened by restrictions upon commercial communications of various kinds, ${ }^{126}$ and it is no stretch from those cases to the conclusion that the right is engaged or burdened by the restrictions in packaging legislation. ${ }^{127}$

123 See Rock v Ireland [1997] 3 IR 484, [1998] 2 ILRM 35 (Hamilton CJ); see, generally, nn 60, 69, 76, 86 and 968 above and n 151 below. In Sweeny v Ireland [2017] IEHC 702 (23 November 2017) Baker J referred to the right to silence derived from Article 40.3; but, for the reasons given in $\mathrm{n}$ 62, this should be read as a reference to Article 40.6.1.

However, in the context of commercial rather than political speech, the US Supreme Court has upheld requirements to disclose purely factual and uncontroversial information (see e.g. Zauderer $v$ Office of Disciplinary Counsel of Supreme Court of Ohio 471 US 626 (1985); Milavetz, Gallop and Milavetz PA v United States 559 US 229 (2010); see generally Robert Post, 'Transparent and Efficient Markets: Compelled Commercial Speech and Coerced Commercial Association' 40 Valparaiso University Law Review 1 (2005); Ellen P Goodman, 'Visual Gut Punch: Persuasion, Emotion, and the Constitutional Meaning of Graphic Disclosure' 99 Cornell Law Review 513 (2014); Robert Post, 'Compelled Commercial Speech' (2015) 117 West Virginia Law Review 867; Micah L Berman, 'Clarifying Standards for Compelled Commercial Speech' 50 (2016) Washington University Journal of Law and Policy 53) which has been followed in lower courts in the context of warnings on tobacco packaging (see e.g. Discount Tobacco City \& Lottery, Inc v United States 674 F3d 509 (6th Cir, 2012); contrast n 55 above).

124 In Society for the Protection of Unborn Children v Grogan (No 5) [1998] 4 IR 343, 390 Keane J held that it is 'a necessary corollary' of Paperlink 'that other citizens have a constitutional right to receive such information'; compare Virginia Board of Pharmacy v Virginia Citizens Consumer Council 425 US 748 (1976) (hearer autonomy); Ford v Quebec [1988] 2 SCR 712, 1988 CanLII 19 (SCC) (15 December 1988) (commercial expression protects listeners as well as speakers).

125 See nn 59 and 109 above.

126 Attorney General v Paperlink [1984] ILRM 373 (courier services); Oblique Financial Services Ltd v The Promise Production Co Ltd [1994] 1 ILRM 74 (financial information); Carrigaline Community Television Broadcasting Co Ltd $v$ Minister for Transport, Energy and Communications [1997] 1 ILRM 241 (rebroadcaster); Murphy v Irish Radio and Television Commission [1999] 1 IR 12, [1998] 2 ILRM 360 (advertising); Colgan v Independent Radio and Television Commission [2000] 2 IR 490, [1999] 1 ILRM 22, [1998] IEHC 117 (20 July 1998) (same); Digital Rights Ireland Ltd v Minister for Communications, Marine and Natural Resources [2010] 3 IR 251, [2010] IEHC 221 (5 May 2010) (telecommunications).

127 Though it may have an impact upon the application of the proportionality test or other standard of review or scrutiny of the restriction; see part 4.3 below. 


\subsection{SPEECH, EXPRESSION, COMMUNICATION}

The Irish Constitution contains two speech rights - a freedom of political expression in Article 40.6.1(i) and a freedom of autonomous communication in Article 40.3.1. Notwithstanding that it began in a narrow reading of Article 40.6.1, ${ }^{128}$ this bifurcated protection now reflects the two general justifications for the protection of freedom of expression, rooted respectively in considerations of democracy and autonomy. ${ }^{129}$ For all that there are strong arguments that the narrow reading of Article 40.6.1(i) and the implication of an unenumerated right into Article 40.3.1 were unnecessary, and that all of the constitutional protections for freedom of speech should be (re-)integrated into Article 40.6.1(i), ${ }^{130}$ it is exceedingly unlikely that the Supreme Court would extirpate a constitutional right to which it has - several times - afforded its imprimatur. ${ }^{131}$ Indeed, there are advantages to this separation: the commingling or conflating of these justifications can be avoided; their different consequences can be independently explored; and their different ambits of application can be clearly identified. All of this ensures that they each can develop in an appropriate fashion; and the Supreme Court should therefore devote its analytical energies to continuing the increasingly expansive approach it is taking to both rights.

In many cases, the coverage of the two rights will be coterminous, or will at least overlap substantially. ${ }^{132}$ So, from the perspective of whether the rights are engaged or burdened, it will often make very little difference which one is invoked. ${ }^{133}$ For example, in both cases, the constitutional text confines the rights to citizens: Article 40.6.1(i) refers to the 'right of the citizens to express freely their convictions and opinions', and Article 40.3.1 refers to 'the personal rights of the citizen'. These provisions could have confined the enjoyment of the constitutional protections of speech to natural persons who are citizens. However, whatever the case for natural persons who are not citizens, ${ }^{134}$ it is now

128 See nn 89 and 94 above.

129 Wojciech Sadurski, Freedom of Speech and its Limits (Kluwer 1999) ch 1; Eric Barendt, Freedom of Speech (2nd edn, Oxford University Press 2005) chs 1 and 2; contrast Larry Alexander, Is There a Right to Freedom of Expression? (Cambridge University Press 2005) chs 7 and 8.

130 Tom Daly, 'Strengthening Irish Democracy: A Proposal to Restore Free Speech to Article 40.6.1(i) of the Constitution' (2009) 31 Dublin University Law Journal (ns) 228; Robert Noonan, 'The Ontology of the Subject of Rights: Post-Modern Perspectives on the Irish Constitution through a Case Study on the Right to Free Speech' (2014) 13(1) Cork Online Law Review 71.

131 On this imprimatur, see nn 112, 114 and 120 above. On the consequent unwillingness to extirpate the right, in NHV v Minister for Justice and Equality [2017] 2 ILRM 105, 113, [2017] IESC 35 (30 May 2017), [12] O'Donnell J (Denham CJ, and Clarke, MacMenamin, Laffoy, Charleton and O'Malley JJ concurring) would have wished to consider afresh whether an unenumerated right to work ought to be implied into Article 40.3, but did not do so because that right was so well established.

132 Murphy $v$ Irish Radio and Television Commission [1999] 1 IR 12, 24-5, [1998] 2 ILRM 360, 372 (Barrington J); Holland v Governor of Portlaoise Prison [2004] 2 IR 573, 590, [2004] IEHC 97 (11 June 2004), [25] (McKechnie J); Mahon v Post Publications [2007] 3 IR 338, 377, [2007] 2 ILRM 1, 15-16, [2007] IESC 15 (29 March 2007), [51] (Fennelly J; Murray CJ and Denham J concurring).

133 Though, again, it may have an impact upon the application of the proportionality test or other standard of review or scrutiny of the restriction; see part 5.3 below.

134 Compare NHV v Minister for Justice and Equality [2017] 2 ILRM 105, 115-116, [2017] IESC 35 (30 May 2017), [17]-[19] (O’Donnell J; Denham CJ, and Clarke, MacMenamin, Laffoy, Charleton and O'Malley JJ concurring) (legitimate distinctions may be drawn between citizens and non-citizens in the application of Article 40.3.1). 
well established that such protections may be enjoyed by corporate entities. ${ }^{135} \mathrm{~A}$ challenge by the tobacco companies to the packaging legislation would not therefore be excluded on this ground.

However, such a challenge could provide a context in which it could very well matter which speech right is invoked. If the restrictions upon the cigarette companies' commercial speech in the packing legislation do not engage or burden the freedom of political expression in Article 40.6.1(i) but do engage or burden the freedom of autonomous communication in Article 40.3.1, then, in this important context, the coverage of the two rights will diverge, and it will make a very great deal of difference indeed which one is invoked. Many of the commercial speech cases involve advertisements; ${ }^{136}$ and the issue almost arose in Dunnes Stores $v$ Mandate, ${ }^{137}$ where the Supreme Court refused an application for an injunction restraining publication of a misleading advertisement. ${ }^{138}$ However, the extent of the constitutional protection of a commercial advertisement under either right was not considered by the court, ${ }^{139}$ and the question of the extent to which the freedom of political expression in Article 40.6.1(i), and the freedom of autonomous communication in Article 40.3.1, as they are now understood, would be engaged or burdened by restrictions upon commercial speech still awaits an appropriate case.

Although these rights have been successfully relied upon in various ways, ${ }^{140}$ they have been successfully relied upon to strike down legislation in very few cases. For example, the freedom of political expression in Article 40.6.1(i) has been relied upon to challenge

135 Carrigaline Community Television Broadcasting Co Ltd v Minister for Transport, Energy and Communications [1997] 1 ILRM 241, 287-8 (Keane J). Almost all of the parties which have successfully invoked Article 40.6.1(i) have been companies (see nn 60-70 above), and it has never been objected that they are not citizens (many of them are not media companies which might qualify for protection as 'organs of public opinion'; see State (Lynch) $v$ Cooney [1982] 1 IR 337, 361 (O’Higgins CJ, for the Court)). Moreover, Article 40.3.1 has been successfully invoked on at least one occasion by a (media) company (see n 112 above); see, generally, Ailbhe O’Neill, The Constitutional Rights of Companies (Thomson Round Hall, Dublin 2007) part III.

136 See nn 108, and 114-15 above, and 203, 249-50 below.

137 [1996] 1 IR 55, [1996] 1 ILRM 384.

138 The court held that the European Communities (Misleading Advertising) Regulations 1988 (SI 134/1988) did not apply to a trade dispute between an employer and a union.

139 The plaintiffs had submitted that there is no constitutionally guaranteed freedom to communicate misleading matters ([1996] 1 IR 55, 58); and the defendants submitted in turn that the plaintiffs could reply to the advertisement in the same newspaper in accordance with their own constitutional rights in Article 40.6.1(i) and Article 40.3 (ibid). However, having rejected the application for the injunction on the basis that the regulations did not apply, the court did not need to consider the constitutional arguments.

140 If the numbers here are right, Article 40.6.1(i) has been expressly invoked successfully in 23 cases (see nn 6070 above) and unsuccessfully in 21 (see nn 71-86 above), which is a success rate of a shade over 52 per cent; and Article 40.3.1 has been expressly invoked successfully in four cases (see nn 110-112 above) and unsuccessfully in seven (see nn 113-118 above), which is a success rate of a shade over 36 per cent. 
legislation in eleven cases; it has been successful in three ${ }^{141}$ and unsuccessful in eight, which gives it a success rate of a shade over 27 per cent. Again, the freedom of autonomous communication in Article 40.3.1 has been relied upon to challenge legislation in three cases, but it has not been successful in any of them, which gives it a 0 per cent success rate. Hence, whichever right is engaged or burdened, the chances of success for any challenge are not great; if only Article 40.3.1 is in play, then the chances look particularly bleak. Either way, the chances of survival for the packaging legislation look especially auspicious.

Of course, in any challenge to the packaging legislation on speech grounds, both the expression and communication freedoms are likely to be invoked; and, given the divergence in their ranges, any such challenge would provide the perfect opportunity to continue the development of the engagement or burdening, inter-relationship and interoperability of the two speech rights as separate protections for political expression and autonomous communication.

\section{Reasons}

Where there is a restriction upon a right, the state may advance 'pressing and substantial'142 reasons to seek to justify the restriction. The prohibitions, regulations and requirements relating to packaging in the packaging legislation may potentially be justified by many reasons, but two in particular stand out: public health and the protection of children.

\subsection{Pressing and substantial Reasons}

In the case of rights protected by the European Convention on Human Rights, a list of pressing and substantial reasons is often provided in the second paragraph of articles protecting rights. For example, Article 10(1) protects 'freedom of expression', and Article 10 (2) sets out a list of legitimate aims on foot which restrictions may be justified. However, other similar constitutional documents are not as helpful. For example, the First Amendment to the US Constitution simply states a protection of 'freedom of speech', and the US Supreme Court assesses whether an appropriate or sufficient state or governmental interest has been established. ${ }^{143}$ Similarly, s 2(b) of the Canadian Charter of Rights and Freedoms secures 'freedom of .. . expression', and s 1 envisages 'reasonable limits' on Charter rights, but it is for the Supreme Court of Canada to assess whether a particular reason is a sufficiently pressing and substantial social objective to

141 See nn 60-62 above. Gerard Hogan, David Kenny and Rachael Walsh, 'An Anthology of Declarations of Unconstitutionality' (2015) 54(2) Irish Jurist (ns) 1, identify 93 such declarations between the adoption of the Constitution in 1937 and the completion of their anthology at the end of 2014. Since the completion of the anthology, one of the listed declarations has been reversed on appeal (Bederev v Ireland [2016] IESC 34 (22 June 2016)); there have been declarations of unconstitutionality in four further cases (Moore v DPP [2016] IEHC 244 (19 April 2016); NHV v Minister for Justice and Equality [2017] 2 ILRM 105, [2017] IESC 35 (30 May 2017) (declaration suspended); [2017] IESC 82 (30 November 2017) (declaration made effective); Sweeny $v$ Ireland [2017] IEHC 702 (23 November 2017); AB v Clinical Director of St Loman's Hospital [2018] IECA 123 (3 May 2018) (declaration suspended)); and one is expected in PC v Minister for Social Protection [2017] IESC 63 (27 July 2017) where the matter was put back for submissions as to remedy. Including all five of these cases, this gives a total of 97 declarations, of which three are presented here as having been granted on the basis of constitutional protections of expression and communication, which is a shade over 3 per cent of the total number of declarations of unconstitutionality.

142 Heaney v Ireland [1996] 1 IR 580, 607, [1994] 2 ILRM 420, 431 (Costello J) affd [1996] 1 IR 580, [1997] 1 ILRM 117.

143 E.g. Reed v Town of Gilbert 576 US _ (2015) (slip op, at 14-15); (Thomas J, for the court) (comprehensive Sign Code regulating the display of outdoor signs unconstitutional; Town did not demonstrate that the Code furthered a compelling governmental interest). 
justify a reasonable limit. ${ }^{144}$ The Irish constitutional protections of speech fall somewhere in the middle, containing some guidance from the text of the relevant Articles, but also including others that can be established in court.

The right to freedom of political expression in Article 40.6.1(i) is hedged with many textual exceptions. According to the first line of Article 40.6, 'liberty for the exercise' of all of the rights in that Article is guaranteed 'subject to public order and morality'. ${ }^{145}$ The middle sentence of Article 40.6.1(i) permits restrictions on the 'rightful liberty of expression' of the 'organs of public opinion' to ensure that they are not 'used to undermine public order or morality or the authority of the State'. ${ }^{146}$ And the final sentence of Article 40.6.1(i) provides that blasphemy, sedition and indecency shall be 'offences ... punishable in accordance with law'. ${ }^{147}$ This gives six grounds on the face of the text. Furthermore, since the exercise of constitutional rights 'may be regulated by the Oireachtas when the common good requires this', ${ }^{148}$ the right to freedom of political expression in Article 40.6.1(i) 'can, in certain circumstances, be limited in the interests of the common good', ${ }^{149}$ as well as on other grounds. ${ }^{150}$ Moreover, the concomitant rights derived from Article 40.6.1(i) are also subject to the same limitations. ${ }^{151}$

On the other hand, the freedom of autonomous communication in Article 40.3.1 is expressly guaranteed 'as far as practicable', and it - as well as concomitant rights derived from it - may also be limited in the interests of the common good. ${ }^{152}$

144 E.g. R v Butler [1992] 1 SCR 452, 491-9, 1992 CanLII 124 (SCC) (27 February 1992) (Sopinka J; Lamer CJ, La Forest, Cory, McLachlin, Stevenson and Iacobucci JJ concurring) (objective of the avoidance of harm to society sufficiently pressing and substantial; prohibition on obscene material proportionate to that objective); R v KRJ [2016] 2 SCR 31, 2016 SCC 31 (21 July 2016), [61]-[66] (Karakatsanis J; McLachlin CJ, Cromwell, Moldaver, Wagner, Gascon and Côté JJ concurring) (objective of protection of children).

145 These are 'overriding considerations' (State (Lynch) v Cooney [1982] IR 337, 361; [1983] ILRM 89, 91 (O’Higgins CJ, for the court)); see also Redmond v Ireland [2015] IESC 98 (17 December 2015), [18] (Charleton J).

146 See State (Lynch) v Cooney [1982] IR 337, 361; [1983] ILRM 89, 94 (O’Higgins CJ, for the court) (authority of the state); Desmond v Glackin [1993] 3 IR 1, 28 (O’Hanlon J) (restriction 'sufficiently wide to comprehend ... authority and impartiality of the judiciary', by analogy with Article 10(2) European Convention on Human Rights).

147 See e.g. Corway v Independent Newspapers (Ireland) Ltd [1999] 4 IR 485, [2000] 1 ILRM 426, [1999] IESC 5 (30 July 1999) (blasphemy); s 36 of the Defamation Act 2000 (blasphemy); ss 11, 12 and 26 of the Offences Against the State Act 1939 (sedition); s 7 of the Censorship of Films Act 1923 (blasphemy, sedition, indecency, public morality); ss 6 and 7 of the Censorship of Publications Act 1929; Irish Family Planning Association v Ryan [1979] IR 295 and Melton Enterprises Ltd v Censorship of Publications Board [2003] 3 IR 623, [2003] IESC 55 (4 November 2003) (indecency, obscenity).

148 Ryan v Attorney General [1965] IR 294, 312-13 (Kenny J), affd [1965] IR 294, 345, [1965] IESC 1 [23] (3 July 1965) (Ó Dálaigh CJ, for the court); O'Callaghan v Ireland [1994] 1 IR 555, 562 (Finlay CJ, for the court); North Western Health Board v HW [2001] 3 IR 622, 740, [2001] IESC 90 (8 November 2001), [228] (Murray J), [2001] 3 IR 622, 760, [2001] IESC 90 [212] (Hardiman J); Dellway Investments v National Asset Management Agency (No 3) [2011] 4 IR 1, 209, [2011] IESC 14 (12 April 2011) [53] (Murray CJ), [2011] 4 IR 1, 225, [2011] IESC 14 [110] (Denham J).

149 Murphy $v$ Irish Radio and Television Commission [1999] 1 IR 12, 25, [1998] 2 ILRM 360, 373 (Barrington J; Hamilton CJ, O'Flaherty, Denham and Keane JJ concurring).

150 In Equality Authority v Portmarnock Golf Club, O'Higgins J in the High Court, in the course of interpreting s 9(1)(a) of the Equal Status Act 2000, held that the Article 40.6.1 right of association could be circumscribed by considerations other than public order and morality ([2005] IEHC 235 (10 June 2005)); the Supreme Court approved his interpretation of s 9(1)(a), but held that he need not have reached the constitutional issue ([2010] 1 IR 671, [2010] 1 ILRM 237, [2009] IESC 73 (3 November 2009)).

151 Heaney $v$ Ireland [1996] 1 IR 580, 589, [1997] 1 ILRM 117, 127 (O'Flaherty J) (correlative right to silence subject to public order and morality); Rock v Ireland [1997] 3 IR 484, 496, [1998] 2 ILRM 35, 45 (Hamilton CJ, for the court) (same); on that right to silence, see nn 60, 62, 69, 76, 86, 96-8 and 123 above.

152 Ryan (n 148 above); Murphy (n 149 above). 
The state can lead expert evidence on these issues. ${ }^{153}$ Indeed, it may be fatal not to.

And so, the question here is simply whether there are 'pressing and substantial' reasons upon which the state may rely to seek to justify the restrictions upon speech contained in the packaging legislation. Public health and the protection of children are the two most likely such reasons.

\subsection{Public health}

Public health is the main reason for the packaging legislation. ${ }^{154}$ In introducing the Bill that became the Public Health (Standardised Packaging of Tobacco) Act 2015, ${ }^{155}$ the Minister for Health, Dr James Reilly, said that tobacco kills 5200 Irish citizens and 700,000 European citizens every year, ${ }^{156}$ and that the aim of the legislation:

$\ldots$ is to make all tobacco packs look less attractive to consumers, to make health warnings more prominent and to prevent packaging from misleading consumers ... about the harmful effects of tobacco. ${ }^{157}$

There is a great deal of evidence that plain packaging will help achieve this aim. ${ }^{158}$ In particular, the Australian measures do seem to be contributing to a decline in tobacco use. ${ }^{159}$

In several leading constitutional decisions, the state has put forward public health reasons to support legislation, often with success. For example, in Ryan $v$ Attorney General, ${ }^{160}$ the court upheld the Health (Fluoridation of Water Supplies) Act 1960 on the grounds that the plaintiff had not established that fluoridation involved any danger to life

153 PJ Carrolls v Minister for Health and Children [2005] IESC 26 (3 May 2005); Digital Rights Ireland v Minister for Communications, Marine and Natural Resources [2017] IEHC 307 (19 July 2017), [19], [26] (Costello J).

154 Compare BAT [2016] EWHC 1169 (Admin) (19 May 2016), [60]-[76] (Green J); affd [2016] EWCA Civ 1182 (30 November 2016), [21]-[27] (Lewison, Beatson and Richards LJJ) (public health concerns underpinning the UK legislation and regulations in n 5 above); JTI (2012) 250 CLR 1, [2012] HCA 43 [4] (French CJ), [145] (Gummow J); [253]-[254] (Crennan J), [308]-[309], [316]-[317] (Kiefel J) (public health concerns underpinning the Australian legislation in n 3 above); but see [193], [209], [227] (Heydon J, dissenting).

155 The minister's statements in the Oireachtas are not admissible (Crilly v Farrigton [2001] 3 IR 251, [2002] 1 ILRM 161, [2001] IESC 60 (11 July 2001)), but they nevertheless constitute a useful guide to what the state would likely argue in defence of the Act.

156 See Seanad Debates (17 June 2014) 40 <https://www.oireachtas.ie/en/debates/debate/seanad/2014-06-17/11/>. He returned to this theme at Final Stage: 'every year 5,200 Irish people die prematurely from smoking. This year alone, more people in this country will die from smoking than died during 30 years of the Troubles in Northern Ireland' (see Seanad Debates (3 March 2015) 2 <https://www.oireachtas.ie/en/debates/debate/seanad/2015-03-03/10/>.

157 See Seanad Debates (17 June 2014) 39 <https://www.oireachtas.ie/en/debates/debate/seanad/2014-06$17 / 11 />$.

158 Final Regulatory Impact Analysis for the Public Health (Standardised Packaging of Tobacco) Bill 2014 <http://health.gov.ie/wp-content/uploads/2013/12/Standardised-Packaging-RIA-July-2014-FINAL.doc>; David Hammond, Standardized Packaging of Tobacco Products (Evidence Review prepared on behalf of the Irish Department of Health) (March 2014) < http:/ / health.gov.ie/wp-content/uploads/2014/06/2014-Ireland-Plain-Pack-MainReport-Final-Report-July-26.pdf $>$. Similarly, an independent review undertaken for the UK government concluded that standardised packaging is "very likely over time to contribute to a modest but important reduction in smoking prevalence'; see Sir Cyril Chantler, Standardised Packaging of Tobacco (3 April 2014) [6.11] 40 <http://webarchive.nationalarchives.gov.uk/20140911094224/http:/www.kcl.ac.uk/health/packagingreview.aspx $>$.

159 The Department of Health, Post-implementation Review of Tobacco Plain Packaging (26 February 2016) $<$ http://ris.pmc.gov.au/2016/02/26/tobacco-plain-packaging >. See also The Economics of Tobacco and Tobacco Control (National Cancer Institute Tobacco Control Monograph Series $21 \quad 2017) 302$ $<$ http://who.int/tobacco/publications/economics/nci-monograph-series-21/en>.

160 [1965] IR 294, [1965] IESC 1 (3 July 1965). 
or health. ${ }^{161}$ In McGee v Attorney General, ${ }^{162}$ while the court struck down s 17 of the Criminal Law Amendment Act 1935 that prohibited the import or sale of contraceptives, Walsh J accepted that there 'may be many reasons, grounded on considerations of public health ...' for such a prohibition. ${ }^{163}$ And in Norris $v$ Attorney General, ${ }^{164}$ the court dismissed a challenge to legislation criminalising male homosexual acts, which the state successfully justified on the grounds, inter alia, of public health. ${ }^{165}$

In Re Philip Clarke, ${ }^{166}$ the court upheld the power of the police to take a person of unsound mind into custody, because it was intended not only for the benefit of such persons but also 'for the safety and well-being of the public generally'. ${ }^{167}$ And in Bederev $v$ Ireland, ${ }^{168}$ the court upheld the power of the government to declare any substance to be a controlled drug for the purposes of the Misuse of Drugs Act 1977. Charleton J said that the Act is 'concerned with the risks to human well-being of allowing dangerous drugs to be available'169 and that its primary aim is 'to protect against the dangers of harm caused by these types of substances' ${ }^{170}$ Furthermore, broader public health concerns have informed various dicta ${ }^{171}$ in the Supreme Court and have been relied upon to uphold

161 [1965] IR 294, 348-9, [1965] IESC 1 (3 July 1965), [28]-[33] (Ó Dálaigh CJ, for the court) (in particular to protect against dental cavities) (not an unconstitutional infringement of the plaintiff's unenumerated right to bodily integrity implied in Article 40.3.1).

162 [1974] IR 284, [1973] IESC 2 (19 December 1973).

163 [1974] IR 284, 308, [1973] IESC 2 (19 December 1973) (Walsh J) (unconstitutional infringement of the plaintiff's unenumerated right to marital privacy implied in Article 40.3.1).

164 [1984] IR 36, [1983] IESC 3 (22 April 1983), upholding ss 61 and 62 of the Offences Against the Person Act 1861, and s 11 of the Criminal Law Amendment Act 1885. The European Court of Human Rights disapproved of that outcome in Norris v Ireland 10581/83 (1988) 13 EHRR 186, [1988] ECHR 22 (26 October 1988 ) and the offence was abolished by s 2 of the Criminal Law (Sexual Offences) Act 1993; but see DPP $v$ Devins [2012] IESC 7 (8 February 2012).

165 [1984] IR 36, 48 (McWilliam J), affd [1984] IR 36, 62, 63, 65 (O’Higgins CJ; Finlay P and Griffin J concurring), 77, 79 (Henchy J, dissenting), 94, 102, 104 (McCarthy J, dissenting), [1983] IESC 3 (22 April 1983).

166 [1950] IR 235, upholding s 165 of the Mental Treatment Act 1945.

167 [1950] IR 235, 247 (O’Byrne J, for the court). The 1945 Act was amended several times and was ultimately repealed and replaced by the Mental Health Act 2001, and Clarke's paternalism has been followed throughout; see Re Gallagher [1991] 1 IR 31, 38 (McCarthy J); Gallagher v Director of the Central Mental Hospital (No 2) [1996] 3 IR 10, 17-18 (Geoghegan J), 36 (Laffoy J) ('protect the public'); Croke v Smith (No 2) [1998] 1 IR 101, 112, 132 (Hamilton CJ); Gooden v St Otteran's Hospital (2001) [2005] 3 IR 617, 634 (McGuinness J); VTS v Health Service Executive [2009] IEHC 106 (11 February 2009) (Edwards J); EH v Clinical Director of St Vincent's Hospital [2009] 3 IR 774, 790, [2009] IESC 46 (28 May 2009) (Kearns J); AB v Clinical Director of St Loman's Hospital [2018] IECA 123 (3 May 2018), [39] (Hogan J; Peart and Gilligan JJ concurring); see Claire Murray, 'Reinforcing Paternalism within Irish Mental Health Law' (2010) 17(1) Dublin University Law Journal (ns) 273.

168 [2016] 2 ILRM 340, [2016] IESC 34 (22 June 2016), upholding s 2(2) of the Misuse of Drugs Act 1977 and the Misuse of Drugs Act 1977 (Controlled Drugs) (Declaration) Order 2011 (SI 551/2011).

169 [2016] 2 ILRM 340, 366, [2016] IESC 34 (22 June 2016), [30] (Charleton J; Denham CJ, and O’Donnell, McKechnie, Clarke, MacMenamin and Dunne JJ concurring).

170 Ibid.

171 Re a Ward of Court [1996] 2 IR 79, 125, [1995] 2 ILRM 401, 427, [1995] IESC 1 (27 July 1995), [149]-[150] (Denham J) (in the case of contagious diseases, the claims of the common good might well justify restrictions on the exercise of a constitutionally protected right to refuse medical treatment) (court permitted withdrawal of medical treatment from ward); Rachel O'Sullivan, 'The Patient's Duties to Others: Limitations to the Principle of Autonomy in Healthcare Decision Making' (2015) 14(1) Cork Online Law Review 7; North Western Health Board v HW [2001] 3 IR 622, 762, [2001] IESC 90 (8 November 2001), [316]-[317] (Hardiman J) (major public health policy decisions are matters in the first place for the legislature, and then for the courts to assess constitutionality) (court upheld parental refusal to consent to blood test on child); Simon Mills, 'Constitutional Law - PKU: Please Keep Unclear?’ (2001) 23 Dublin University Law Journal (ns) 180. 
other impugned legislation. ${ }^{172}$ Moreover, the state may also argue that such public health concerns implicate not just matters of important public policy, but also the state's duty to vindicate the rights of its citizens. In Ryan, Kenny J in the High Court and Ó Dálaigh CJ in the Supreme Court accepted that the right to bodily integrity is among the unenumerated personal rights guaranteed by Article 40.3 .1 of the Constitution. ${ }^{173}$ That capacious and accommodating article might in an appropriate case also provide a home for a right to health. ${ }^{174}$ And the duty to vindicate these rights could reinforce the state's interest in public health. ${ }^{175}$

In the context of constitutional protections of freedom of speech, the courts have held that the right to life can, in principle, limit such rights. ${ }^{176}$

The state has been permitted to rely on public health concerns in many cases to defend legislation, often with success; and similar concerns have been relied upon in the context of speech rights. Moreover, the state's interest in the promotion of public health was central to PJ Carrolls v Minister for Health and Children, ${ }^{177}$ in which the Supreme Court held that the state could lead expert evidence of the harmful effects of smoking to meet a challenge to tobacco advertising prohibitions in the Public Health (Tobacco) Act 2002. For all of these reasons, therefore, the public health concerns underpinning the packaging legislation undoubtedly constitute pressing and substantial reasons upon which the state may seek to justify standardised packing restrictions.

172 Re Article 26 and the Health (Amendment) (No 2) Bill 2004 [2005] 1 IR 105, 174, [2005] IESC 7 (16 February 2005) [63] (provision of health services); BUPA Ireland Ltd v Health Insurance Authority [2006] IEHC 431 (23 November 2006), [242]-[247], [293]-[294] (McKechnie J) (private medical insurance involves major issues of national policy, including state interest in functioning and fair health insurance market).

173 [1965] IR 294, [1965] IESC 1 (3 July 1965), [23]; see also McGee v Attorney General [1974] IR 284, [1973] IESC 2 (19 December 1973); Re a Ward of Court [1996] 2 IR 73, [1995] 2 ILRM 401, [1995] IESC 1 (27 July 1995).

174 See e.g. Allen Buchanan, Justice and Health Care (Oxford University Press 2009); John Tobin, The Right to Health in International Law (Oxford University Press 2012); Jonathan Wolff, The Human Right to Health (Norton, New York 2012); John Tasioulas and Effy Vayena, 'The Place of Human Rights and the Common Good in Global Health Policy' (2016) 37 Theoretical Medicine and Bioethics 365. The Supreme Court has rejected the justiciability of economic, social and cultural rights (Sinnott v Minister for Education [2001] 2 IR 545; TD v Minister for Education [2001] 4 IR 259); but there are strong arguments the other way (see e.g. Gerry Whyte, Social Inclusion and the Legal System: Public Interest Law in Ireland (Institute of Public Administration, Dublin 2002); Anne Hughes, Human Dignity and Fundamental Rights in South Africa and Ireland (Pretoria University Law Press 2014)). In particular, Article 45 includes a reference to 'the strength and health of workers, men and women' (Article 45.4.2; emphasis added); on the justiciability of Article 45, see Gerard Hogan, 'Directive Principles, Socio-Economic Rights and the Constitution' (2001) 36 Irish Jurist (ns) 174. The development of a justiciable constitutional right to health, perhaps as an unenumerated right to health implied into Article 40.3.1, cannot therefore be excluded (though in NHV v Minister for Justice and Equality [2017] 2 ILRM 105, 113, [2017] IESC 35 (30 May 2017), [12] O’Donnell J (Denham CJ, and Clarke, MacMenamin, Laffoy, Charleton and O’Malley JJ concurring) seemed particularly unwilling to countenance the implication of socio-economic rights into that Article). Note that in 2014 the Constitutional Convention voted to afford greater constitutional protection to such rights (see <www.constitution.ie/AttachmentDownload.ashx?mid=adc4c56a-a09c-e311-a7ce005056a32ee4>).

175 It might also lighten the applicable standard of review; see part 5.7 below.

176 Attorney General (Society for the Protection of the Unborn Child) v Open Door Counselling [1988] IR 593, 625 (Finlay CJ) (see n 80 above) (right to life of the unborn child); Foley $v$ Sunday Newspapers Ltd [2005] IEHC 14 (28 January 2005) (Kelly J) (defamation, interlocutory injunction to protect plaintiff's life refused); Murray v Newsgroup Newspapers Ltd [2011] 2 IR 156, [2010] IEHC 248 (18 June 2010) (Irvine J) (invasion of privacy, interlocutory injunction to protect plaintiff's life refused).

177 [2005] IESC 26 (3 May 2005); see also BUPA Ireland v Health Insurance Authority [2006] IEHC 431 (23 November 2006), [246] (McKechnie J); Ryan v Attorney General [1965] IR 294, 343, [1965] IESC 1 (3 July 1965) [15] (Ó Dálaigh CJ, for the court) (admissibility of scientific evidence in constitutional challenge). 


\subsection{PROTECTION OF CHILDREN}

The protection of children is an important reason for the 2015 Act. In introducing the Bill that became the 2015 Act, the Minister for Health, Dr James Reilly, said that tobacco 'will kill one in two of the children seduced by its packaging and gimmicks into taking up the killer habit', ${ }^{178}$ and that the aim of the legislation was to 'prevent packaging from misleading consumers, particularly children, about the harmful effects of tobacco'. ${ }^{179}$ Hence, limiting youth access to tobacco products is a tobacco control imperative worldwide. ${ }^{180}$

In Landers v Attorney General, ${ }^{181}$ Finlay J upheld a prohibition upon children performing in licensed premises after $9 \mathrm{pm}$, on the ground, inter alia, that the protection of children must be part of the common good. ${ }^{182}$ Moreover, the state may also argue that such concerns implicate not just matters of important public policy, but also the state's duty to vindicate children's rights, ${ }^{183}$ which are expressly secured by Article $42 \mathrm{~A} .1$ of the Constitution. ${ }^{184}$

For these reasons, the concerns to protect children underpinning the packaging legislation undoubtedly constitute pressing and substantial reasons upon which the state may seek to justify standardised packing restrictions. So, too, do the state's interests in the promotion of public health. These conclusions hold, whether those concerns or interests are described as exigencies of the common good, strong public policies, legitimate aims, or pressing and substantial reasons.

\section{Review}

It is clear that, where there is a restriction upon a right, the state may advance 'pressing and substantial' reasons to seek to justify the restriction. However, it is not enough for the state to advance such reasons; those reasons must support and justify the restrictions, and not go too far in doing so. In the case of rights protected by the European Convention on Human Rights, this question of review or scrutiny arises because the rights that it protects may often be limited for reasons that are 'necessary in a democratic society'. In the case of rights protected by the Canadian Charter of Rights and Freedoms, this question arises because the rights that it protects may be limited for reasons that 'can be demonstrably justified in a free and democratic society'. Hence, in

178 See Seanad Debates (17 June 2014) 40 (n 156 above).

179 See Seanad Debates (17 June 2014) 39 (emphasis added) (n 157 above).

180 See The Economics of Tobacco and Tobacco Control (n 159) ch 11.

181 Landers v Attorney General (1975) 108 ILTR 1, 5 (Finlay J) upholding s 2(b)-(c) of the Prevention of Cruelty to Children Act 1904; see also Norris v Attorney General [1983] IESC 3 (22 April 1983), [1984] IR 36, 79 (Henchy J, dissenting), 104 (McCarthy J, dissenting) (protection of young is an aspect of the common good).

182 (1975) 108 ILTR 1, upholding s 2(b) and (c) of the Prevention of Cruelty to Children Act 1904.

183 It might also lighten the applicable standard of review; see part 5.7 below.

184 The text is set out after $\mathrm{n} 259$ below. It was inserted by the 31st Amendment of the Constitution, which came into effect in 2015; as to the prior position, compare $G v A n$ Bord Uchtála [1980] IR 32, 55 (O’Higgins CJ); Eastern Health Board v An Bord Uchtála [1994] 3 IR 207, 230 (O’Flaherty J); DG v Eastern Health Board [1997] 3 IR 511, 525 (Hamilton CJ), 533-6 (Denham J); North Western Health Board v HW [2001] 3 IR 622, 719-20 (Denham J). 
both the European Court of Human Rights ${ }^{185}$ and the Supreme Court of Canada, ${ }^{186}$ this standard has been interpreted to require that the restriction must be proportionate to the reason for it. ${ }^{187}$

Following this lead, 188 the Irish Supreme Court has strongly committed to a proportionality test to review or scrutinise legislative restrictions upon constitutional rights; the impugned legislation must:

(a) be rationally connected to the objective and not be arbitrary, unfair or based on irrational considerations;

(b) impair the right as little as possible; and

(c) be such that its effects on rights are proportional to the objective. ${ }^{189}$

The court has applied this test across the constitutional board, including in the context of the freedom of political expression in Article 40.6.1,190 and of the freedom of

185 Handyside v UK 5493/72 (1976) 1 EHRR 737, [1976] ECHR 5 (7 December 1976), [49]; Jeremy McBride, 'Proportionality and the European Convention on Human Rights' in Evelyn Ellis (ed), The Principle of Proportionality in the Laws of Europe (Hart, Oxford 1999) ch 2; Yutaka Arai-Takahashi, The Margin of Appreciation Doctrine and the Principle of Proportionality in the Jurisprudence of the ECHR (Intersentia 2002); Andrew Legg, The Margin of Appreciation in International Human Rights Law. Deference and Proportionality (Oxford University Press 2012); Mattias Klatt and Moritz Meister, The Constitutional Structure of Proportionality (Oxford University Press 2012); contrast Stijn Smet, Resolving Conflicts between Human Rights: The Judge's Dilemma (Routledge, London 2017).

186 R v Oakes [1986] 1 SCR 103, 1986 CanLII 46 (SCC) (28 February 1986), [70] (Dickson CJ; Chouinard, Lamer, Wilson and Le Dain JJ concurring); Sujit Choudry, 'So What is the Real Legacy of Oakes? Two Decades of Proportionality Analysis under the Canadian Charter's Section 1' (2006) 34 Supreme Court Law Review (2d) 501; David Bilchitz, 'Necessity and Proportionality: Towards a Balanced Approach' in Liora Lazarus, Christopher McCrudden and Nigel Bowles (eds), Reasoning Rights. Comparative Judicial Engagement (Hart, Oxford 2016) ch 3; Dwight Newman, 'Canadian Proportionality Analysis: 51/2 Myths' (2016) 73 Supreme Court Law Review (2d) 93.

187 Aharon Barak, Proportionality: Constitutional Rights and Their Limitations (Cambridge University Press 2012).

188 And contributing to international dialogue on the issue; see Kai Möller, 'Constructing the Proportionality Test: An Emerging Global Conversation' in Lazarus et al (n 186) 31; contrast Oran Doyle, 'Constitutional Cases, Foreign Law and Theoretical Authority' (2016) 5(1) Global Constitutionalism 85 (defending judicial use of foreign law as a matter of persuasive authority, but not as a matter inter-jurisdictional judicial dialogue).

189 Heaney v Ireland [1996] 1 IR 580, 607, [1994] 2 ILRM 420, 431 (Costello J), affd [1996] 1 IR 580, [1997] 1 ILRM 117 (SC); Rock v Ireland [1997] 3 IR 484, 500, [1998] 2 ILRM 35, 49-50 (Hamilton CJ, for the court); Re National Irish Bank [1999] 3 IR 145, 178-80, [1999] 1 ILRM 321, 352, [1999] IESC 18 [26]-[31] (21 January 1999) (Barrington J; O’Flaherty, Murphy, Lynch and Barron JJ concurring); Blehein v Minister for Health and Children [2009] 1 IR 275, 281, [2008] IESC 40 (10 July 2008), [18] (Denham J; Hardiman, Geoghegan, Kearns and Macken JJ concurring); Leech v Independent Newspapers (Ireland) Ltd [2014] IESC 79 (19 December 2014) [20]-[24] (McKechnie J); see, generally, Brian Foley, 'The Proportionality Test: Present Problems' [2008] Judicial Studies Institute Journal 67. See, in particular, DK v Crowley [2002] 2 IR 744, 757-8 (Keane CJ, for the court), striking down the procedures for barring orders in s 4(3) of the Domestic Violence Act 1996 as a disproportionate infringement of applicant's constitutional right to fair procedures.

190 Murphy v Irish Radio and Television Commission [1999] 1 IR 12, 26, [1998] 2 ILRM 360, 373 (Barrington J; Hamilton CJ, O'Flaherty, Denham, and Keane JJ concurring); Colgan v Independent Radio and Television Commission [2000] 2 IR 490, 508-9, [1999] 1 ILRM 22, 41-2, [1998] IEHC 117 (20 July 1998), [41]-[42] (O’Sullivan J); Dunne Stores v Ryan [2002] IEHC 61 (5 June 2002), [40], [68] (Kearns J); K (A Minor) v Independent Star [2010] IEHC 500 (3 November 2010), [83]-[85] (Hedigan J); Robert Cannon, 'Does Expression Have Any Freedom Left? Murphy v Independent Radio and Television Commission' (1998) 1 Trinity College Law Review 126; Rachel Joyce, 'A New Approach to Freedom of Expression? The Doctrine of Proportionality and Article 40.6.1(i) of the Constitution' (2003) 3 Hibernian Law Journal 85. 
autonomous communication in Article 40.3.1.191 And it would almost ${ }^{192}$ certainly be applied in any challenge by tobacco companies to the packaging legislation.

\subsection{RATIONAL CONNECTION}

The first of the three steps in the proportionality test is a requirement of a rational connection, that the impugned legislation must be rationally connected to the pressing and substantial reasons advanced by the state, and not be arbitrary, unfair or based on irrational considerations. Hence, restrictions that were struck down as being 'impermissibly wide and indiscriminate'193 are now explained as being disproportionate, ${ }^{194}$ as are 'unreasonable' or 'unnecessary' restrictions. ${ }^{195}$

The requirement of a rational connection assesses the strength or weakness of the state's reasons for the restriction. The less pressing and substantial they are, the less likely a restriction is to be proportionate. For example, regulations that were 'neither capricious nor arbitrary'196 have been easily upheld. Conversely, the more pressing and substantial they are, the more likely a restriction is to be proportionate. For example, an 'extreme financial crisis or fundamental disequilibrium in the public finances' ${ }^{\prime 197}$ could justify very significant restrictions indeed.

The question here, then, is whether the packaging legislation passes the requirement of a rational connection. Subject to the evidence on this point that might be run in any challenge, the answer would seem to be yes. The state's interests in the promotion of public health and in the protection of children ${ }^{198}$ are unquestionably pressing and substantial reasons; the packaging legislation is clearly rationally connected to them; and it does not seem to be arbitrary, unfair or based on irrational considerations.

\subsection{Minimal IMPAIRMENT}

The second of the three steps in the proportionality test is a requirement of minimal impairment, that the impugned legislation must impair the engaged or burdened right as little as possible: the interference must not exceed what is necessary to meet the pressing

191 Murphy (n 190); Colgan (n 190); Holland v Governor of Portlaoise Prison [2004] 2 IR 573, [2004] IEHC 97 (11 June 2004), [32]-[33] (McKechnie J).

192 Subject to part 5.7 below.

193 Cox v Ireland [1992] 2 IR 503, 524 (Finlay CJ, for the court), striking down s 34 of the Offences Against the State Act 1939; see also PC v Minister for Social Protection [2017] IESC 63 (27 July 2017), [57], ("punitive, retributive, indiscriminate, and disproportionate') (MacMenamin J; Denham CJ and McKechnie, Clarke J and O’Malley JJ concurring).

194 Heaney $v$ Ireland [1996] 1 IR 580, 607, [1994] 2 ILRM 420, 431 (Costello J) (Cox (ibid) an 'example of . . . disproportionate means'); Rock v Ireland [1997] 3 IR 484, 500, [1998] 2 ILRM 35, 49 (Hamilton CJ, for the court) (proportionality 'surfaced obliquely' in Cox); McCann v Minister for Education [1997] 1 ILRM 1, 10-11 (Costello P); Re Article 26 and the Employment Equality Bill 1996 [1997] 2 IR 321, 342-3, 383 (Hamilton CJ, for the Court).

195 DK v Crowley [2002] 2 IR 744, 762 (Keane CJ, for the court); Aughey v Ireland [1989] ILRM 87, 93 (Walsh J; Henchy J, Griffin, Hederman and McCarthy JJ concurring) (no 'unreasonable or disproportionate' restriction of constitutional right to associate). Other synonymous descriptions of restrictions (see e.g. nn 237, 240 below) should also be accommodated in this way.

196 Lawlor v Minister for Agriculture [1990] 1 IR 356, 377, [1988] ILRM 400, 418 (HC, Murphy J).

197 Re Article 26 and the Health (Amendment) (No 2) Bill 2004 [2005] 1 IR 105, 208, [2005] IESC 7, [132] (Murray CJ, for the court); J\&J Haire v Minister for Health [2010] 2 IR 615, 654-5, [2009] IEHC 562, [122]-[123] (McMahon J), upholding ss 2 and 9 of the Financial Emergency Measures in the Public Interest Act 2009; Dellway Investment v National Asset Management Agency [2011] 4 IR 1, 120, [287], [2010] IEHC 364 (1 November 2010) [10.20] (Kearns P, Kelly and Clarke JJ, in a joint judgment).

198 See part 4 above. 
and substantial concerns in question and must be the least possible interference with the right consistent with the advancement of those concerns. ${ }^{199}$ Hence, the imposition of 'relatively minor' 200 burdens or 'limited' 201 intrusions upon rights have been held to be minimal and thus proportionate interferences with those rights. On the other hand, in Dunnes Stores $v$ Ryan, ${ }^{202}$ Kearns J in the High Court struck down a provision requiring a company to provide a statement to an officer making inquiries about the company on the grounds that it failed the minimal impairment step of the proportionality test because it did not immunise those statements from later use in criminal proceedings.

The court has not always applied this requirement with strictness. In Murphy $v$ Irish Radio and Television Commission, Barrington $\mathrm{J}$ held that the impugned advertising restrictions were 'minimalist', notwithstanding that a 'more selective administrative system' could have been possible. ${ }^{203}$

The requirement of minimal impairment assesses the strength or weakness of a restriction upon a right. A regulation of speech is less intrusive than a ban upon speech, so regulation is more likely to be a proportionate restriction than an outright ban. On the one hand, in Murphy $v$ Irish Radio and Television Commission, Barrington J held that the restrictions did not involve the complete removal of all means of expression and stressed that the applicant could advance his views in other ways. ${ }^{204}$ On the other hand, in Holland $v$ Governor of Portlaoise Prison, McKechnie J struck down a 'total and absolute abolition'205 of the plaintiff's Article 40.6.1(i) rights.

The question here, then, is whether the packaging legislation passes the requirement of minimal impairment. Again, subject to the evidence on this point that might be run in any challenge, the answer would seem to be yes. These are unquestionably pressing and substantial reasons; the packaging legislation, whilst extensive, seems to impair the engaged or burdened speech rights as little as possible; in particular, there do not seem to be any plausible less restrictive means available to the state to the achieve the same ends.

\subsection{PROPORTIONAL EFFECTS}

The third of the three steps in the proportionality test is a requirement of proportional effects, that the effects of the impugned legislation on the engaged or burdened rights must be proportional to the pressing and substantial reasons advanced by the state.

199 Reid v Industrial Development Agency [2015] IESC 82 (5 November 2015), [44](iv) (McKechnie J; Denham CJ, O’Donnell, Laffoy and Charleton JJ concurring); Keane v An Bord Pleannála (No 3) [1998] 2 ILRM 241, 262 (Keane J; Hamilton CJ and Barrington J concurring) (abridgements of property rights must go no further than required by the exigencies of the common good).

200 Electricity Supply Board v Gormley [1985] IR 129, 152, [1985] ILRM 494, 502 (Finlay CJ, for the court); compare Canadian Pacific Railway Co v Vancouver (City) [2006] 1 SCR 227, 2006 SCC 5 (23 February 2006), [30], [34] (McLachlin CJ; Bastarache, Binnie, LeBel, Deschamps, Fish and Abella JJ concurring) (does not involve the complete removal of all reasonable uses) (emphasis added); see, generally, Sarah Hamill, 'Common Law Property Theory and Jurisprudence in Canada' (2015) 40(2) Queen's Law Journal 679.

201 Chestvale Properties Ltd v Glackin [1993] 2 IR 35, 45 (Murphy J); Dellway Investments v National Asset Management Agency (No 3) [2011] 4 IR 1, 327, [2011] IESC 14 (12 April 2011), [456] (Fennelly J).

202 [2002] IEHC 61 (5 June 2002); see nn 60-1 above.

203 [1999] 1 IR 12, 26-7, [1998] 2 ILRM 360, 374 (Barrington J; Hamilton CJ, O’Flaherty, Denham, and Keane JJ concurring). This conclusion may be explained as a strong example of judicial deference to legislative judgment; see part 5.4 below.

204 Ibid.

205 [2004] 2 IR 573, 603, [2004] IEHC 97, [47]. 
Hence, where even a minor transgression has an excessive consequence, ${ }^{206}$ the legislation will be disproportionate and unconstitutional.

The requirement of proportional effects assesses the strength or weakness of the right which the state has pressing and substantial reasons to restrict: the more central the restricted activity is to the enjoyment of the right in question, the less likely the restriction will be proportionate, whereas the further the restricted activity is from the core of the right, the more likely a restriction is to be proportionate.

To the extent that the speech restrictions in the packaging legislation restrict commercial speech, the freedom of political expression in Article 40.6.1(i) may not be engaged or burdened at all, ${ }^{207}$ though the freedom of autonomous communication in Article 40.3.1 may be. ${ }^{208}$ However, as with speech clauses elsewhere, ${ }^{209}$ commercial speech is not central to that freedom. ${ }^{210}$

The question here, then, is whether the packaging legislation passes the requirement of proportionate effects. Again, subject to the evidence on this point that might be run in any challenge, the answer would seem to be yes. In particular, their speech rights are not central to the freedoms or protections engaged or burdened by the restrictions in the packaging legislation.

\subsection{DEFERENCE}

The courts are particularly reluctant to second guess legislative judgments on controversial $^{211}$ or sensitive 212 social, economic and medical matters and on major issues of national policy. Accordingly, in applying the three steps of the proportionality test, courts often afford a great deal of deference to the state. ${ }^{213}$ Hence, in a strong (perhaps overly strong) example of judicial deference to legislative judgment, in Murphy v Independent Radio and Television Commission, Barrington J for the Supreme Court held that:

... once the Statute is broadly within the area of the competence of the Oireachtas and the Oireachtas has respected the principle of proportionality, it is not for this Court to interfere simply because it might have made a different decision. ${ }^{214}$

206 Cox v Ireland [1992] 2 IR 503, 524 (Finlay CJ, for the court), as explained in Murphy v Irish Radio and Television Commission [1999] 1 IR 12, 26-7, [1998] 2 ILRM 360, 374 (Barrington J; Hamilton CJ, O'Flaherty, Denham, and Keane JJ concurring); see also PC v Minister for Social Protection (n 193 above) [33] (MacMenamin J).

207 See text in paragraph with $n 106$ above.

208 See text in paragraph with $\mathrm{n} 126$ above.

209 See text in paragraph with n 136 above and with nn 249-50 below.

210 See n 108 above.

211 Ryan v Attorney General [1965] IR 294, 312 (Kenny J); Dellway Investment v National Asset Management Agency [2011] 4 IR 1, 119-20, [284]-[287], [2010] IEHC 364 (1 November 2010), [10.17]-[10.20] (Kearns P, Kelly and Clarke JJ, in a joint judgment) affd Dellway Investments v National Asset Management Agency (No 3) [2011] 4 IR 1, 225 [2011] IESC 14 (12 April 2011), [110] (Denham J).

212 MD v Ireland [2012] IESC 10 (23 February 2012), [50] (Denham CJ; Murray, Hardiman, Fennelly and Macken JJ concurring).

213 BUPA Ireland v Health Insurance Authority [2006] IEHC 431 (23 November 2006), [247] (McKechnie J); but see David Dyzenhaus, 'Proportionality and Deference in a Culture of Justification' in Grant Huscroft, Bradley W Miller and Grégoire Webber (eds), Proportionality and the Rule of Law. Rights, Justification, Reasoning (Cambridge University Press 2014) ch 11.

214 [1999] 1 IR 12, 27, [1998] 2 ILRM 360, 374 (Barrington J; Hamilton CJ, O’Flaherty, Denham, and Keane JJ concurring). In Colgan v Independent Radio and Television Commission [2000] 2 IR 490, 512, [1999] 1 ILRM 22, 45 [1998] IEHC 117 (20 July 1998) O'Sullivan J explained this as reflecting an appropriate 'degree of judicial restraint'. 
In Colgan v Independent Radio and Television Commission, O'Sullivan $\mathrm{J}$ in the High Court suggested that this judicial restraint 'may itself be an application of the presumption of constitutionality', 215 by which legislation enacted by the Oireachtas after the Constitution came into force in 1937 is presumed to be constitutional, unless and until the contrary is clearly established. ${ }^{216}$ The court has applied this presumption in the context of the freedom of political expression in Article 40.6.1217 and of the freedom of autonomous communication in Article 40.3.1.218 The packaging legislation would certainly benefit from the presumption and from any attendant judicial deference to legislative judgment.

This presumption of constitutionality is certainly a strong force driving such deference. And it leads to two further presumptions. First, it is presumed that the Oireachtas intended a constitutional construction of legislation; so where constitutional and non-constitutional constructions are reasonably open, the court must choose the constitutional one. ${ }^{219}$ And, again, the courts have applied this presumption in the context of political expression 220 and of autonomous communication. ${ }^{221}$ The packaging legislation would certainly benefit from this presumption too.

Second, the presumption of constitutionality leads to the further presumption that a statutory discretion will be exercised constitutionally 222 and that fair procedures will be followed. ${ }^{223}$ And, again, the courts have applied this presumption in the context of political expression. ${ }^{224}$ The making of a statutory instrument by the Minister for Health, pursuant to the packaging legislation, ${ }^{225}$ would certainly benefit from this presumption too.

\subsection{HIGHER STANDARDS OF REVIEW}

In the case of rights protected by the US Constitution, the Supreme Court has developed several standards of review or scrutiny by which to assess the validity of legislative restrictions upon rights. The strictest level of scrutiny requires the state to demonstrate that impugned restrictions are narrowly tailored to serve compelling state interests. ${ }^{226}$

215 [2000] 2 IR 490, 512, [1999] 1 ILRM 22, 45, [1998] IEHC 117 (20 July 1998); see, generally, Brian Foley, Deference and the Presumption of Constitutionality (Institute of Public Administration, Dublin 2008).

216 The classic statements are Pigs Marketing Board v Donnelly (Dublin) Ltd [1939] IR 413, 417 (Hanna J); McDonald $v$ Bord na gCon [1965] IR 217, 239 (Walsh J); East Donegal Co-operative Livestock. Mart Ltd v Attorney General [1970] IR 317, 340-1 (Walsh J); see most recently Collins v Minister for Finance [2016] IESC 73 (16 December 2016), [70] (Denham CJ, and O'Donnell, McKechnie, Clarke, Dunne and Charleton JJ, in a joint judgment).

217 Murphy v Independent Radio and Television Commission [1999] 1 IR 12, 27, [1998] 2 ILRM 360, 374-5 (Barrington J; Hamilton CJ, O’Flaherty, Denham, and Keane JJ concurring).

218 Ibid; Rock v Ireland [1997] 3 IR 484, 500-1, [1998] 2 ILRM 35, 40 (Hamilton CJ, for the court).

219 McDonald v Bord na gCon [1965] IR 217, 239 (Walsh J); East Donegal Co-operative Livestock Mart Ltd v Attorney General [1970] IR 317, 340-1 (Walsh J).

220 State (Lynch) v Cooney [1982] 1 IR 337, 360 (O’Higgins CJ, for the court); see also nn 66, 74-6 and 85 above.

221 See n 117 above.

222 East Donegal Co-operative Livestock Mart Ltd v Attorney General [1970] IR 317, 340-1 (Walsh J).

223 Garvey v Ireland [1981] IR 75, 97 (O’Higgins CJ); Dellway Investments v National Asset Management Agency (No 3) [2011] 4 IR 1, 282, [2011] IESC 14 (12 April 2011), [311] (Hardiman J).

224 State (Lynch) v Cooney 1982 IR 337, 380 (Henchy J; O’Higgins CJ, Walsh, Griffin and Hederman JJ concurring); see $\mathrm{n} 71$ above. By analogy, this presumption would also apply in the context of the right to autonomous communication.

225 See nn 5 and 6 above.

226 RAV v St Paul 505 US 377, 395 (1992) (Scalia J, for the court) (viewpoint discrimination restriction triggering strict scrutiny); Citizens United v Federal Election Commission 558 US 310, 340 (2010) (Kennedy J, for the court) (restriction on political speech triggering strict scrutiny); Reed v Town of Gilbert 576 US _ (2015) (slip op, at 14-15) (Thomas J, for the court) (content-based restriction triggering strict scrutiny). 
This certainly resembles 227 the Irish proportionality test, 228 though with the burden of proof reversed. ${ }^{229}$ There are some passing references to 'strict scrutiny' in Irish cases, ${ }^{230}$ including some speech ${ }^{231}$ cases. The Supreme Court may therefore come to embrace an enhanced proportionality rule, perhaps by analogy with strict scrutiny, that would cast a justificatory burden upon the state for particularly serious kinds of infringements of particularly important rights. However, the court has reserved the question of whether such an approach is required by, or compatible with, the Constitution. ${ }^{232}$

The tobacco companies may take up this invitation and seek to persuade the court to subject the packaging legislation to such strict scrutiny, in the hope that the legislation would not survive such a high degree of scrutiny. However, it is hard to see how strict scrutiny would square with the strong commitment to the presumption of constitutionality, ${ }^{233}$ which plainly imposes the burden of proving the unconstitutionality of the statute upon the party affected by the statute rather than upon the state. So, unless that presumption is modified, this argument would not succeed. Moreover, even if it would, it is unlikely to avail the tobacco companies, for two reasons. First, if enhanced proportionality is triggered by particularly serious kinds of infringements of particularly important rights, it is hard to see how commercial speech meets this standard. Second, the public health and protection of children concerns ${ }^{234}$ underpinning the packaging legislation would very likely meet any justificatory burden cast upon the state.

There is a second standard of review on which the tobacco companies might also seek to rely. In the US, legislation which restricts substantially more free speech than would be

227 Vicki C Jackson, 'Constitutional Law in an Age of Proportionality’ (2015) 124 Yale Law Journal 2680, 3136; as to the nature and extent of the resemblance, see, generally, Jacco Bomhoff, Balancing Constitutional Rights: The Origins and Meanings of Postwar Legal Discourse (Cambridge University Press 2013); Moshe Cohen-Eliya and Iddo Porat, Proportionality and Constitutional Culture (Cambridge University Press 2013); Vicki C Jackson and Mark Tushnet, Proportionality. New Frontiers, New Challenges (Cambridge University Press 2017).

228 In Rafferty v Minister for Agriculture, Food and Rural Development [2014 IESC 61 (7 November 2014), [45] Denham CJ (Murray, Hardiman, O'Donnell and McKechnie JJ concurring) referred to both 'strict scrutiny' and 'proportionality' in the same sentence. The High Court ([2008] IEHC 344 (31 October 2008)) had held that a narrow interpretation of the word 'compensation' in s 17 of the Diseases of Animals Act 1966 was constitutional, but Denham CJ provided a broader interpretation without reference to constitutional considerations; compare Dublin Corporation v Underwood [1997] 1 IR 69 (SC).

229 David Kenny, 'Proportionality, the Burden of Proof, and Some Signs of Reconsideration' (2014) 52 Irish Jurist (ns) 141, arguing that, following the Canadian lead (see n 186 above) the state should (at least in some cases) bear the burden of demonstrating the proportionality of impugned legislation.

230 Certain comments of Keane J (Barrington J concurring) in the Supreme Court in Simple Imports Ltd v Revenue Commissioners [2000] 2 IR 243, 250, [2000] IESC 40 (19 January 2000), [19] have been represented as requiring 'strict scrutiny of warrants' (LC Autolink Ltd v Feebily [2008] IEHC 397 (12 December 2008), [50] (MacMenamin J); Damache v DPP [2011] IEHC 197 (13 May 2011) (Kearns P) rvsd without reference to this point [2012] IESC 11 (23 February 2012)). In Rafferty v Minister for Agriculture, Food and Rural Development [2014] IESC 61 (7 November 2014), [45] (Denham CJ; Murray, Hardiman, O’Donnell and McKechnie JJ concurring) referred to strict scrutiny of compulsory purchase. See also An Blascaod Mór Teorenta v Commissioners of Public Workes (No 3) [1998] IEHC 38 (27 February 1998), [164] (Budd J) ('construe strictly' a compulsory purchase), discussing Tormey $v$ Commissioners of Public Works (Supreme Court, unreported, 20 December 1968) (Ó Dálaigh CJ, for the court, at p 6 of the transcript) ('look strictly' at compulsory purchase).

231 Mahon v Post Publications [2007] 3 IR 338, [2007] 2 ILRM 1, [2007] IESC 15 (29 March 2007), [85] (Fennelly J; Murray CJ and Denham J concurring) (strict scrutiny of prior restraint).

232 Fleming v Ireland [2013] 2 IR 417, 454-5, [2013] IESC 19 [140] (Denham CJ, for the court). In the earlier D (a Minor) v Ireland [2010] IEHC 101 (26 March 2010) Dunne J had held that 'presumptive unconstitutionality' on the basis of 'strict scrutiny' was unsupported by the authorities cited to her.

233 See part 5.4 above.

234 See part 4 above. 
justified by a statute's plainly legitimate sweep is overbroad 235 and unconstitutional, unless a limiting construction can be placed on the impugned provision. ${ }^{236}$ In Ireland, references to overbreadth have largely been as synonyms for findings of a lack of proportionality, ${ }^{237}$ and the stricter US doctrine does not seem to have gained a foothold. ${ }^{238}$ Moreover, the current commitment to judicial deference, and the strong form of the double construction rule, both generated by the presumption of constitutionality, make such a development as unlikely as the development of an enhanced proportionality rule casting a justificatory burden upon the state. Besides, it is not clear that the packaging legislation is overbroad in any event.

It is, therefore, very unlikely that the packaging legislation would be subject to a higher level of review or scrutiny than the three-step proportionality test above. Moreover, even if it were, the legislation would be very unlikely to fail such review or scrutiny.

\subsection{ALTERNATIVE STANDARDS OF REVIEW}

In the US Supreme Court, alongside strict scrutiny, various factors trigger alternative standards of review. ${ }^{239}$ To the extent that they feature at all in the case law of the Irish Supreme Court, they have been accommodated as examples of the application of the proportionality test. ${ }^{240}$ The High Court of Australia is developing an alternative formulation of the proportionality test, ${ }^{241}$ which the Supreme Court has not had the opportunity to consider. It is, therefore, very unlikely that the packaging legislation would be subject to any of these alternative standards of review or scrutiny.

235 Broadrick v Oklahoma 413 US 601 (1973) (recognising overbreadth, holding statute was not overbroad); Virginia $v$ Hicks 539 US 113 (2003) (same).

236 Osborne v Obio 495 US 103 (1990).

237 Blehein v Minister for Health and Children [2009] 1 IR 275, 281, [2008] IESC 40 (10 July 2008), [18] (Denham J; Hardiman, Geoghegan, Kearns and Macken JJ concurring) (limitation on a right 'should not be overbroad, should be proportionate, and should be necessary to secure the legitimate aim'). In NHV v Minister for Justice and Equality [2016] 1 ILRM 453, 501, [2016] IECA 86 (14 March 2016), [122]-[124] Hogan J (dissenting) held that the restriction failed the proportionality test and was invalid by reason of 'constitutional overbreadth'; on appeal ([2017] 2 ILRM 105, [2017] IESC 35 (30 May 2017)) the Supreme Court reversed the majority in the Court of Appeal, but did not reach this aspect of Hogan J's dissent. Compare Open Door and Dublin Well Woman v Ireland 14234/88 and 14235/88 (1993) 15 EHRR 244, [1992] ECHR 68 (29 October 1992), [74] (restriction 'over broad and disproportionate') (see n 83 above); Obukhova v Russia 34736/03 [2009] ECHR 4 (8 January 2009), [27] (restriction 'excessively broad and disproportionate'); on accommodating these cases within proportionality, see $n 195$ above.

238 David Kenny, 'A Dormant Doctrine of Overbreadth: Abstract Review and Ius Tertii in Irish Proportionality Analysis' (2010) 37(1) Dublin University Law Journal (ns) 24.

239 Brandenburg $v$ Obio 395 US 444, 447 (1969) (per curiam) (incitement of imminent lawless action; refashioning 'clear and present danger' test); New York Times Cov United States 403 US 713, 714 (1971) (per curiam) (prior restraints bear a 'heavy presumption' against constitutional validity).

240 Mahon v Post Publications [2007] 3 IR 338, 374, 381, [84]-[85], [109]-[110], [2007] 2 ILRM 1, 13, 19-20, [2007] IESC 15 [40]-[41], [65]-[66] (29 March 2007) (Fennelly J; Murray CJ and Denham J concurring).

241 McCloy $v$ New South Wales (2015) 257 CLR 178, [2015] HCA 34 (7 October 2015); Murphy v Electoral Commissioner [2016] HCA 36 (5 September 2016). 


\subsection{LOWER AND VARIABLE STANDARDS OF REVIEW}

In the US Supreme Court, below strict scrutiny, various factors trigger intermediate 242 and lower levels of scrutiny. ${ }^{243}$ Moreover, some few matters are historically 244 outside the protection of the Constitution altogether. In particular, commercial speech ${ }^{245}$ is subject to its own specialist intermediate level of scrutiny.

Although the European Court of Human Rights starts from a unitary proportionality test, it achieves similar results by applying it and related doctrines ${ }^{246}$ in a flexible or variable fashion, ${ }^{247}$ often in the guise of balancing competing rights and interests. ${ }^{248}$ In particular, commercial speech 249 is subject to such a light application of the proportionality test that restrictions for public health reasons routinely survive review. ${ }^{250}$

Irish law is adopting both of these strategies. It applies the proportionality test in a flexible or variable fashion, assessing the strengths and weaknesses of the restrictions, rights and reasons at issue in the cases. ${ }^{251}$ And it is also clearly developing alternative, lower, standards of review. ${ }^{252}$ In particular, where the Supreme Court considers that the Oireachtas is essentially engaged in a balancing of constitutional rights and duties, the role of the court is not to impose its view of the correct or desirable balance in substitution for the view of the legislature as displayed in its legislation, but rather to

242 United States v O'Brien 391 US 367, 377 (1968) (Warren CJ, for the court) (content-neutral regulations of symbolic speech); Ward $v$ Rock against Racism 491 US 781, 797-8 (1989) (Kennedy J for the court) (contentneutral regulations of reasonable time, place, or manner regulations of speech).

243 Miller v California 413 US 15, 24-6 (1973) (Burger CJ, for the court) (obscenity); International Society for Krishna Consciousness, Inc v Lee 505 US 672 (1992) (restriction on expressive activity in an airport terminal, as a nonpublic forum, satisfied rational basis test).

244 United States v Stevens 559 US 460, 469-71 (2010) (Roberts CJ, for the court) (declining to extend the list of matters historically outside the First Amendment).

245 Central Hudson Gas \& Electric Corp v Public Service Commission of New York 447 US 557, 566 (1980) (Powell J, for the court); Sorrell v IMS Health Inc 564 US 552, 572 (2011) (Kennedy J, for the court).

246 George Letsas, 'Two Concepts of the Margin of Appreciation' (2006) 26(4) Oxford Journal of Legal Studies 705; Matthew Saul, 'The European Court of Human Rights' Margin of Appreciation and the Processes of National Parliaments' (2015) 15(4) Human Rights Law Review 745.

247 Murphy v Ireland 44179/98 (2003) 38 EHRR 212, [2003] ECHR 352 (10 July 2003) (see n 74 above); Mouvement Raëlien Suisse v Switzerland 16354/06 (2013) 56 EHRR 14, [2012] ECHR 1598 (13 July 2012); see, generally, Julian Rivers, 'Proportionality and Variable Intensity of Review' (2006) 65(1) Cambridge Law Journal 174.

248 On the legitimacy of balancing as part of the proportionality test, see Kai Möller, The Global Model of Constitutional Rights (Oxford University Press 2012), and contrast Niels Petersen, 'Balancing and Judicial Selfempowerment: A Case Study on the Rise of Balancing in the Jurisprudence of the German Federal Constitutional Court' (2015) 4(1) Global Constitutionalism 49 with Jochen von Bernstorff, 'Proportionality without Balancing: Why Judicial Ad Hoc Balancing is Unnecessary and Potentially Detrimental to the Realisation of Individual and Collective Self-determination' in Lazarus et al (186) 63.

249 Barthold v Germany 8734/79 (1985) 7 EHRR 383, [1985] ECHR 3 (25 March 1985); Market Intern Verlag GmbH and Klaus Beermann v Germany 10572/83 (1990) 12 EHRR 161, [1989] ECHR 21 (20 November 1989); Casado Coca v Spain 15450/89 (1994) 18 EHRR 1, [1994] ECHR 8 (24 February 1994); Stambuck v Germany 37928/97 (2003) 37 EHRR 42, [2002] ECHR 679 (17 October 2002).

250 See Amandine Garde, 'Freedom of Commercial Expression and the Protection of Public Health in Europe' (2010) 12 Cambridge Yearbook of European Legal Studies 225; Amandine Garde, 'Freedom of Commercial Expression and Public Health Protection: The Principle of Proportionality as a Tool to Strike the Balance' in Niamh Nic Shuibhne and Laurence W Gormley (eds), From Single Market to Economic Union. Essays in Honour of John Usher (Oxford University Press 2012) ch 6. See also C 547/14 R (Philip Morris Brands Sarl) v Secretary of State for Health (ECLI:EU:C:2016:325; CJEU, 4 May 2016), [146]-[162] (tobacco packing regulations proportionate restrictions on speech).

251 See parts 5.2 and 5.4 above.

252 Oran Doyle, 'Judicial Scrutiny of Legislative Classification' (2012) 47 Irish Jurist (ns) 175 ('differentiated tiers of scrutiny' and 'positions of relative deference'). 
determine from an objective stance whether the balance contained in the impugned legislation is so contrary to reason and fairness as to constitute an unjust attack on some individual's constitutional rights. ${ }^{253}$

In this rationality test, there are significant echoes both of the US rational basis test ${ }^{254}$ and of the UK's ultimate balancing test, ${ }^{255}$ and either of these lines of authority might influence its development. It is a lower, less stringent, more tractable standard of review or scrutiny than the three-step proportionality test. Even so, legislation can fail this test ${ }^{256}$ and be found unconstitutional.

On the other hand, it has, on occasion, been treated as equivalent ${ }^{257}$ to proportionality; and it might yet be absorbed into that test, perhaps as a context of deference to the Oireachtas 258 and a flexible application of the test. However, for the time being, it is better to treat it as a separate rationality standard of review or scrutiny.

If the packaging legislation is justifiable not only on the basis of the state's interests in public health and the protection children, but also on the basis of constitutional rights, ${ }^{259}$ then the state may seek to argue that its constitutionality should be assessed on the basis of this rationality standard rather than on the basis of the stricter three-step proportionality standard. Article 42A.1 of the Constitution provides:

The State recognises and affirms the natural and imprescriptible rights of all children and shall, as far as practicable, by its laws protect and vindicate those rights.

If the packaging legislation were to be seen as an aspect of the state's duty to vindicate the rights of all children, then the appropriate standard of review or scrutiny would be the rationality test rather than the proportionality test. And, if the rationality test were to applied, then the packaging legislation would certainly survive review or scrutiny; it could not be said that the balance of rights contained in the packaging legislation is 'so

253 Touby $v$ Courtney [1994] 3 IR 1, 47 (Finlay CJ, for the court); Re Article 26 and the Regulation of Information (Services Outside the State for the Termination of Pregnancies) Bill, 1995 [1995] 1 IR 1, 45, [1995] 2 ILRM 81, 109 (Hamilton CJ, for the court); Iarnród Éireann v Ireland [1996] 3 IR 321, 376, [1996] 2 ILRM 500, 508 (O'Flaherty J, for the court); In re Article 26 and the Employment Equality Bill, 1996 [1997] 2 IR 321, 334 (Hamilton CJ, for the court).

254 E.g. Federal Communications Commission v Beach Communications, Inc 508 US 307 (1993); Romer v Evans 517 US 620 (1996); Lawrence v Texas 539 US 558 (2003).

$255 \operatorname{Re} S$ (a Child) [2005] AC 593, 603, [2004] UKHL 47 (28 October 2004), [17] (Lord Steyn; Lords Bingham, Nicholls, Hoffmann and Carswell concurring); Rugby Football Union v Consolidated Information Services Ltd [2012] 1 WLR 3333, 3346-7, [2012] UKSC 55 (21 November 2012), [44]-[45] (Lord Kerr; Lord Phillips, Lady Hale, Lord Clarke and Lord Reed concurring); Khuja (formerly PNM) v Times Newspapers [2017] UKSC 49 (19 July 2017), [33] (Lord Sumption; Lord Neuberger, Lady Hale, Lord Clarke and Lord Reed concurring).

256 Re Article 26 and the Health (Amendment) (No 2) Bill 2004 [2005] 1 IR 105, 198, [2005] IESC 7 [115] (Murray CJ, for the court) (striking down retrospective health charges). White v Dublin City Council [2004] 1 IR 545, 568-9, [2004] 2 ILRM 509, 531, [2004] IESC 35 (10 June 2004), [80] (Denham J; Murray, McGuinness, Fennelly and McCracken JJ concurring), striking down an absolute two-month limitation period in s 82(3B)(a)(i) of the Local Government (Planning and Development) Act 1963, as inserted by s 19(3) of the Local Government (Planning and Development) Act 1992.

257 In the Health Bill Reference (n 256) and in Rock v Ireland [1997] 3 IR 484, [1998] 2 ILRM 35, both tests are referred to, semble as equivalent. In BUPA Ireland v Health Insurance Authority [2006] IEHC 431 (23 November 2006), [238], [248], [297] McKechnie J set out both proportionality and Touby $v$ Courtney, and seemed to treated them as equivalent, but expressed his conclusion exclusively in proportionality terms. In Shirley v O'Gorman [2006] IEHC 27 (31 January 2006) Peart J perceived an 'overlap' between Tuoby $v$ Courtney and proportionality.

258 In re Article 26 and the Employment Equality Bill, 1996 [1997] 2 IR 321, 343 (Hamilton CJ, for the court); An Blascaod Mor Teo v Commissioners of Public Works (No 4) [2000] 3 IR 565, 590 (Budd J); Shirley v O'Gorman (n 257) (Peart J); BUPA Ireland v Health Insurance Authority (No 2) [2013] IEHC 103 (7 March 2013), [96] (Cooke J).

259 See, generally, part 4 above. 
contrary to reason and fairness' as to constitute an unjust attack on the tobacco companies' speech rights.

\subsection{ABSENCE OF REVIEW}

It is now clear that legislation restricting rights will be subjected to a standard of review or scrutiny. It was not always so clear. In State (Lynch) $v$ Cooney, ${ }^{260}$ it was enough for O'Higgins CJ that the legislation restricting the plaintiff's speech rights was designed to protect the constitutionally sanctioned legitimate aim of 'the authority of the State'. This judgment predates the development of the proportionality and rationality standards of review or scrutiny discussed above. To the extent that it could preclude further review or scrutiny once a pressing and substantial reason to justify the legislation has been established, then it can no longer be right. ${ }^{261}$ It is unthinkable that the packaging legislation would not be subject to some standard of review or scrutiny. The only question is which one: a tractable rationality test, or a more stringent three-step proportionality test, or some other test. And, in answer to that question, it is clear that the packaging legislation would satisfy any applicable test.

\section{Conclusion}

Restrictions upon rights can be justified by reasons that survive review. The Public Health (Standardised Packaging of Tobacco) Act 2015 and part 5 of the Health (Miscellaneous Provisions) Act 2017 together provide for comprehensive standardised packaging of tobacco products. Some elements of packaging are prohibited, others are regulated, and still others are required; and there are strict regulations upon, perhaps even prohibitions of, the use of trade marks and other branding.

These restrictions potentially engage or burden the speech rights contained in the Irish Constitution. There are two relevant two relevant Articles of the Constitution. The right 'to express freely . . . convictions and opinions' contained in Article 40.6.1(i) of the Constitution is a freedom of political expression. The unenumerated right to communicate, implied in Article 40.3.1, is a freedom of autonomous communication. Despite unpropitious beginnings, this bifurcation now provides a largely stable and relatively coherent basis for analysis and development. While the political and autonomous cores of the freedoms are now reasonably well established, it is not yet clear how far, if at all, beyond such core concerns these freedoms extend. Given that it is the tobacco companies' commercial speech that would be affected by the restrictions, it is not clear whether the freedom of political expression would be engaged or burdened, but it is clear, at least as a matter of authority, that their freedom of autonomous communication would be, albeit commercial speech is not at the core of that freedom.

260 [1982] 1 IR 337 (SC); contrast the approach of O’Hanlon J in the court below: [1982] 1 IR 337,355 (considering how far the state may go to restrict freedom of speech).

261 This is not to say that, if an appropriate standard of review or scrutiny were applied, the result in the case would be different, so it might still be rightly decided on its facts; it is only to say that it cannot be right that no standard of review or scrutiny would be applied.

As to whether s 31 would survive review or scrutiny, so that State (Lynch) v Cooney (n 71) would be rightly decided on its facts, see Purcell v Ireland 15404/89 [1991] ECHR 77 (16 April 1991) (challenge to s 31 as contrary to Article 10 ECHR rejected as manifestly ill-founded); see also $\mathrm{R} v$ Secretary of State for the Home Department, ex parte Brind [1991] 1 AC 696, [1991] UKHL 4 (7 February 1991) (upholding similar UK powers); Brind v UK 18714/91 (1994) 18 EHRR CD76, [1994] ECHR 57 (9 May 1994) (challenge to UK powers as contrary to Article 10 European Convention on Human Rights rejected as manifestly ill-founded). 
In public health and the protection of children, the state has pressing substantial reasons for the restrictions; and it may even be said that it is vindicating its citizens' right to health, and children's rights.

In reviewing the impact of the restrictions in the packaging legislation on the tobacco companies' speech rights against the backdrop of the state's protection of public health and children, the legislation must satisfy a three-step proportionality test of rational connection, minimal impairment and proportional effects. Because commercial speech is not at the core of the freedom of autonomous communication, it is easier to restrict it proportionally. In other jurisdictions, commercial speech rights are subject to such a light application of the proportionality test that restrictions for public health reasons routinely survive review or scrutiny; and it is no different here.

It is unlikely that Irish law will develop a stricter test of review of scrutiny without significant modifications to the presumption of constitutionality. However, if the court considers that the packaging legislation seeks to balance the tobacco companies' speech rights against citizens' right to health, and children's rights, then the legislation would have to satisfy only a rationality test, which it easily would.

Ireland has been in the vanguard of tobacco control worldwide. With the Public Health (Standardised Packaging of Tobacco) Act 2015 and part 5 of the Health (Miscellaneous Provisions) Act 2017, it continues to set a very important example. The constitutional validity of these packaging restrictions would underpin a crucial element of the Department of Health's moves towards a tobacco-free Ireland by 2025. And the pack of cigarettes, with large warning photos dominating standardised packaging, would be Cohen's little Parthenon no longer.

\section{Appendix}

Relevant provisions of the Irish Constitution:

\section{Article 40}

$\ldots$

31 The State guarantees in its laws to respect, and, as far as practicable, by its laws to defend and vindicate the personal rights of the citizen.

2 The State shall, in particular, by its laws protect as best it may from unjust attack and, in the case of injustice done, vindicate the life, person, good name, and property rights of every citizen.

...

61 The State guarantees liberty for the exercise of the following rights, subject to public order and morality:

(i) The right of the citizens to express freely their convictions and opinions.

The education of public opinion being, however, a matter of such grave import to the common good, the State shall endeavour to ensure that organs of public opinion, such as the radio, the press, the cinema, while preserving their rightful liberty of expression, including criticism of Government policy, shall not be used to undermine public order or morality or the authority of the State.

The publication or utterance of blasphemous, seditious, or indecent matter is an offence which shall be punishable in accordance with law. 